\title{
Estimation of water storage changes in small endorheic lakes in Northern Kazakhstan
}

\author{
Vadim Yapiyev $^{\mathrm{a}, \mathrm{b}, *}$, Kanat Samarkhanov ${ }^{\mathrm{c}}$, Nazym Tulegenova ${ }^{\mathrm{d}}$, Saltanat Jumassultanova ${ }^{\mathrm{e}}$, \\ Anne Verhoef ${ }^{f}$, Zarina Saidaliyeva ${ }^{g}$, Nursultan Umirov ${ }^{\mathrm{a}}$, Zhanay Sagintayev ${ }^{\mathrm{a}}$, \\ Assel Namazbayevah \\ a Department of Civil and Environmental Engineering, School of Engineering, 53 Kabanbay Batyr Ave, Nazarbayev University, Astana, 010000, Kazakhstan \\ b National Laboratory Astana, Nazarbayev University, Astana, Kazakhstan \\ ${ }^{\mathrm{c}}$ State Key Laboratory of Desert and Oasis Ecology, The XinJiang Institute of Ecology and Geography, The University of Chinese Academy of Sciences, Urumqi, 830011, \\ China \\ d Laboratory to Monitor Engineering Constructions, School of Engineering, Nazarbayev University, Astana, Kazakhstan \\ e Gumilyov Eurasian National University, Astana, Kazakhstan \\ ${ }^{\mathrm{f}}$ Department of Geography and Environmental Science, The University of Reading, Reading, United Kingdom \\ ${ }^{g}$ Institute of Geography, Almaty, Kazakhstan \\ ${ }^{\text {h }}$ Computational Center, Kazhydromet, Astana, Kazakhstan
}

\section{A R T I C L E I N F O}

\section{Keywords:}

Endorheic

Lake

Central Asia

Evaporation

Semi-arid

Kazakhstan

Climate change

Landsat

Burabay

\begin{abstract}
A B S T R A C T
Both climate change and anthropogenic activities contribute to the deterioration of terrestrial water resources and ecosystems worldwide, with Central Asia and its endorheic lakes being among the most severely affected. We used a digital elevation model, bathymetry maps and Landsat images to estimate the areal water cover extent and volumetric storage changes for eleven small terminal lakes in Burabay National Nature Park (BNNP) in Northern Kazakhstan from 1986 to 2016. Based on the analysis of hydrometeorological observations, lake water balance, lake evaporation and Budyko equations, driven by gridded climate and global atmospheric reanalysis datasets, we evaluate the impact of historical climatic conditions on the water balance of the BNNP lake catchments. The total surface water area of the BNNP lakes decreased by around $7 \%$ for that period, mainly due to a reduction in the extent of three main lakes. In contrast, for some smaller lakes, the surface area increased. Overall, we attribute the decline of the BNNP lakes' areal extent and volume to the prolonged periods of water balance deficit when lake evaporation exceeded precipitation. However, during the most recent years (2013-2016) precipitation increased and the BNNP lake levels stabilized.
\end{abstract}

\section{Introduction}

As observed in recent decades (Seddon et al., 2016), the vast waterlimited steppe regions of Central Asia are among the areas most affected by climate variability and change. Central Asia, together with the Middle East, also exhibits the largest share (over 70\%) of worldwide net loss of permanent water extent; which can be attributed to both climate change and anthropogenic impacts (Pekel et al., 2016). Central Asia's territory, where surface water bodies are the main source of fresh water for human needs, consists mostly of endorheic drainage basins including various large terminal (endorheic) lakes such as the Aral Sea, Caspian Sea, Lake Balkhash, and Issyk-Kul Lake (Bai et al., 2012, 2011; Klein et al., 2014; Yapiyev et al., 2017a). These lakes are particularly vulnerable to climate change and anthropogenic mismanagement. Therefore, it is imperative that these lakes are monitored carefully (Mason et al., 1994). In this context, Klein et al. (2014), using mediumresolution remote sensing data, estimated the seasonal changes in the extent of large lake systems and water reservoirs in Central Asia between 1986 and 2012. They report a decrease of surface water area of the Tengiz-Korgaldzhyn lake system in northern Kazakhstan from 1990 to 2012, whereas the water cover extent for Alakol-Sasykol lakes in eastern Kazakhstan remained fairly stable over this period. Focusing on the northeast of Central Asia, Shikano et al. (2006) used NOAA's Advanced Very High Resolution Radiometer (AVHRR) satellite images (with a spatial resolution of $1.1 \mathrm{~km}$ ) for 1999-2004 (ice-free periods only), combined with meteorological data and a simple evaporation

\footnotetext{
${ }^{*}$ Corresponding author. Department of Civil and Environmental Engineering, School of Engineering, 53 Kabanbay Batyr Ave, Nazarbayev University, Astana, 010000, Kazakhstan.

E-mail address: vyapiyev@nu.edu.kz (V. Yapiyev).
} 
model, to estimate and analyze the seasonal and interannual surface water area changes of the Chany lake system in south-west Siberia. They conclude that seasonal (from spring to summer) declines in surface water area are considerable, and are caused by the rapid growth and related water uptake of submerged vegetation, and evaporation from the lake, while the year-to-year variability in water extent is not significant (Shikano et al., 2006).

While most of the published research on Central Asia focusses on large lakes (Bai et al., 2012, 2011; Klein et al., 2014; Propastin, 2012), there are a large number of smaller endorheic lakes, which are often also important for local water resources, and for the preservation of rare ecosystems and biodiversity.

For this paper, we investigate the long-term (30 year) changes in areal extent, volume and water balance of eleven small terminal lakes located in Burabay National Nature Park (BNNP), a previously unstudied area. BNNP is situated on the southern edge of Northern Eurasia where Siberian land surfaces (such as boreal forests or taiga, characterized by energy-limited evapotranspiration) transcend into waterlimited steppes. BNNP is a popular tourist destination famous for its unique tectonic lakes, pine forests inhabited with endemic plant and animal species, as well as beautiful landforms (Yapiyev et al., 2017b). The lakes are one of the most valuable features of BNNP, however not as a major source for human water consumption, but rather as recreational sites that also contribute to local ecosystem functions (Yapiyev et al., 2017b). The importance of these lakes is illustrated by the following fact: in 2008, to protect BNNP lakes from further water level decline, the Kazakh government prohibited direct water abstraction (limited groundwater abstraction is still allowed) from the lakes and constructed a water pipeline, originating in a reservoir situated around $200 \mathrm{~km}$ from BNNP, for local domestic water use needs (Yapiyev et al., 2017b).

The (changing) climatic conditions for this distinct region, combined with its terrestrial water and energy balance flux partitioning characteristics, affect regional precipitation and lake evaporation in a unique fashion, and hence the extent and volume of these endorheic lakes, where evaporation is an important term of the water balance (Yapiyev et al., 2017b).

The findings presented in this paper were obtained using a combination of remote sensing data, GIS tools and bathymetry surveys, together with an evaporation model, water abstraction data, and a brief analysis of anthropogenic impacts on the lakes' water storage. Similar studies on lakes/inland water bodies in Eurasia and elsewhere use either exclusively remote sensing data (Donchyts et al., 2016; Pekel et al., 2016), at times combined with simple climatic analyses (Bai et al., 2012; Klein et al., 2014; Shikano et al., 2006) and sometimes in-situ bathymetry surveys (Zhang et al., 2011). Our study combines all of these techniques in order to achieve a deeper understanding of the lakeenvironment interactions in this region.

\section{Study area}

BNNP (centered on $53^{\circ} \mathrm{N}, 70^{\circ} \mathrm{E}$ ) is located in the Akmola Province in northern Kazakhstan in Northern Central Asia (Fig. 1). The climate in BNNP is continental, resulting in cold and semi-arid conditions (Yapiyev et al., 2017b). The following BNNP lakes were considered (11 in total): Ulken Shabakty, Kishi Shabakty, Shortandy, Burabay, Akkol, Zhaynak, Maybalyk, Tekekol, Gornoe, Karasie, and Svetloe (Fig. 1). For three of these lakes, long-term hydrometeorological observations are available: Ulken Shabakty, Shortandy, and Burabay Lakes (Fig. 1 and Table 1), and the bulk of our hydrometeorological analyses, and related discussion, have been conducted for these three lakes. Six BNNP lake watersheds (see Fig. 1) are part of the Esil-Tobyl river basin that belongs to the vast $\mathrm{Ob}$ river basin draining into the Arctic Ocean. These catchments became endorheic about 100 years ago when water levels of Shortandy Lake fell below a discharge threshold to the single remaining outlet, the Kylshakty River (Fig. 1) (Yapiyev et al., 2017b). A recent review provides a comprehensive background description of the climate, geology, soils, vegetation, landcover, lakes and hydrological processes in BNNP (Yapiyev et al., 2017b).

\section{Data and methods}

\subsection{Digital elevation model, bathymetry, Landsat, and KazEoSat-2 data}

In order to estimate the long-term area and volume changes of the lakes, we used a Digital Elevation Model (DEM) of the watersheds combined with information on the physiography of the lakes' floor based on digitized bathymetry maps (Fig. 2) and Landsat imagery to derive lake shorelines (Fig. 3). The flow diagram illustrates the remote sensing and GIS data processing steps, tools and methods described in this section (see Fig. 4).

\subsubsection{Digital elevation and bathymetry models}

We used the Shuttle Radar Topography Mission (SRTM) DEM with $30 \mathrm{~m}$ pixel resolution (Farr et al., 2007). Shortandy and Ulken Shabakty Lakes have relatively deep basins (maximum depths of 22 and $25 \mathrm{~m}$, respectively, see Table 1) and surface area extent data alone are not sufficient to estimate changes in water storage. Hence, we used recent bathymetry maps to infer the physiography of the lake floor to allow us to estimate water storage changes more accurately. The bathymetry maps were obtained from Kazakh State Hydrometeorological Agency (Kazhydromet) in the form of high quality scanned images together with a coordinate system (WGS-84) and grid. The maps were based on bathymetrical surveys of the lakes conducted in 2012 and 2013 by Kazhydromet, by means of an echo sounder (EA400 SP; Kongsberg Maritime AS), combined with concurrent vessel-based GPS measurements (Seapath $20 \mathrm{NAV}$, Kongsberg Maritime AS). The distance between traverses was $100 \mathrm{~m}$ (Burabay Lake) and $150-200 \mathrm{~m}$ for Shortandy and Ulken Shabakty Lakes respectively. The survey data were processed in QUINSy (Quality Integrated Navigation System) hydrographic data acquisition, navigation and processing software package (QPS B. V.).

The bathymetry maps were digitized, so that they could be used in GIS in order to develop digital bathymetry models. Georeferencing of the bathymetry maps was conducted by using the Georeferencer tool of QGIS (Quantum GIS Desktop, version 2.16) for the preparation of the digital bathymetry models of the physiography of the lake floor for Burabay, Ulken Shabakty and Shortandy lakes. Coordinates from the bathymetric maps were taken as ground control points. The georeferenced points on the bathymetry maps were matched with Landsat images and Open Street Map data. Finally, the depth of the lakes was digitized (the coordinates and depth values of measured points from a georeferenced raster bathymetry map were transformed into vector points) and preliminary georeferenced bathymetric map point geographic data layers for each lake with $\mathrm{Z}$ values (shape files) were created. Data were projected in the WGS-84/UTM-42N coordinate reference system.

For the determination of the water volume and delineation of watersheds, an interpolated surface was created. SRTM DEM and bathymetric data for the BNNP lakes were then converted to a triangulated irregular network (TIN) surface using ArcGIS (ArcGIS Desktop, version 10.3.1) to render a 3D representation of the BNNP basins (Fig. 2).

\subsubsection{Landsat and KazEOSat-2 multispectral data and remote sensing accuracy estimation}

The Landsat dataset provides a long-term global record of moderateresolution (pixel size ranging from 15 to $60 \mathrm{~m}$ ) satellite imagery of the Earth since the early 1970s (NASA). We downloaded cloud-free Landsat images (https://earthexplorer.usgs.gov/) from 1986 to 2016 for the icefree periods (May-October; one image per year, but note that cloud-free Landsat multispectral data were not available for 1997 and 1998). An example of an image in RGB composition is given in Fig. 3. The 


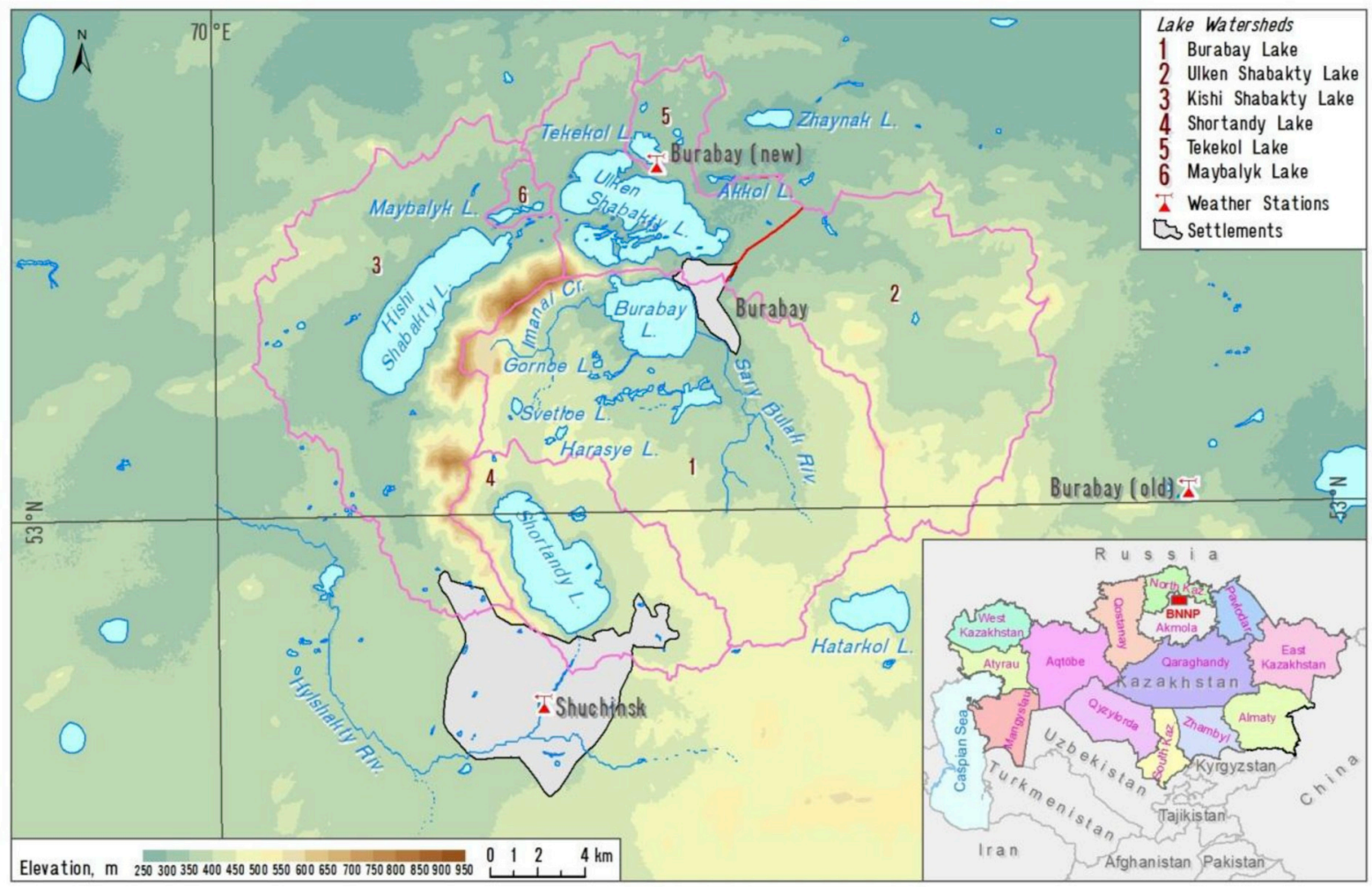

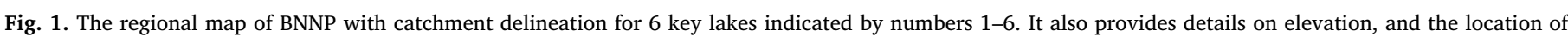

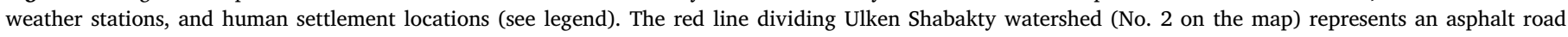

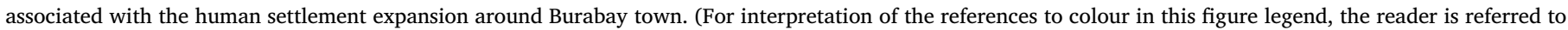
the Web version of this article.)

following spectral bands of Landsat were used: Blue (Band 1, wave-

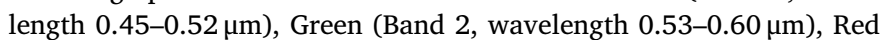
(Band 3, wavelength 0.62-0.69 $\mu \mathrm{m}$ ) and Panchromatic (Band 8, wavelength $0.52-0.90 \mu \mathrm{m})$.

The lakes in the study area are relatively small in size; therefore, to verify the accuracy of the lake surface area extent estimations derived from Landsat data, we compared these data with estimates obtained from higher resolution satellite images. For this verification exercise we used data from the KazEOSat-2 satellite launched on 19 June 2014. It was designed primarily to provide multispectral data for the Kazakhstani territory (European Space Agency, 2018). Its multispectral camera, KEIS (Kazakh Earth Imaging System), is a JSS-56 (Jena-Optronik Spaceborne Scanner-56) multispectral imager. Sensors register signals of 5 bands: Blue $(0.45-0.52 \mu \mathrm{m})$, Green $(0.53-0.60 \mu \mathrm{m})$, Red $(0.62-0.69 \mu \mathrm{m})$, Red-Edge $(0.69-0.73 \mu \mathrm{m})$ and Infra-Red $(0.76-0.89 \mu \mathrm{m})$. Swath width is $77 \times 77 \mathrm{~km}$ and spatial resolution is $6.5 \mathrm{~m}$, radiometric resolution is 12 bits. The orbit is sun-synchronous at $630 \mathrm{~km}$ height. The KazEOSat-2 is able to cover 1 million $\mathrm{km}^{2}$ day $^{-1}$ (European Space Agency, 2018) For the satellite image intercomparison study, we used a recent Landsat- 8 image $(30 \mathrm{~m}$ resolution pan sharpened to spatial resolution of $15 \mathrm{~m}$ ) dated 03.05.2016 and a KazEOSat-2 image dated 05.09.2016, and applied the methodology of water surface area estimation described in Section 3.2.

\subsection{Lake surface water area and storage calculations}

The ENVI application (Exelis Visual Information Solutions Inc., version 5.3) was used to perform a supervised classification and to extract water shorelines as polygon vector objects. In order to carry out the supervised classification we combined Red (Band 4), Green (Band 3) and Blue (Band 2) bands of each selected Landsat image to obtain RGB compositions. Landsat 7 and 8 images were pan sharpened (using Band 8) to improve spatial resolution (see Table S1 in the Supplementary materials). Due to the fact that spectral signatures of lakes are considerably different from other objects in the images, and the fact that their areas are considerable, the spectral angle mapping method of supervised classification was selected. Since the lakes can be easily recognized on these images, several training polygons were drawn. The class 'water' was created to allow extraction of pixels corresponding to water objects. These data were exported to shapefile format and the

Table 1

Some morphometric characteristics of three main BNNP lakes, which are the focus of this study.

\begin{tabular}{lllllll}
\hline Lake & $\begin{array}{l}\text { Lake Surface Area, } \boldsymbol{S A}_{\boldsymbol{L}} \\
\left(\mathrm{km}^{2}\right)^{4}\end{array}$ & $\begin{array}{l}\text { Catchment Surface* Area, } \boldsymbol{S A}_{\boldsymbol{C}} \\
\left(\mathrm{km}^{2}\right)\end{array}$ & $\begin{array}{l}\text { Ratio Catchment/Lake Surface } \\
\text { Area, } \boldsymbol{r}_{\boldsymbol{S A}}\end{array}$ & $\begin{array}{l}\text { Max. Depth } \\
(\mathrm{m})\end{array}$ & $\begin{array}{l}\text { Average }{ }^{3} \text { Depth } \\
(\mathrm{m})\end{array}$ & $\begin{array}{l}\text { Lake Volume, } \boldsymbol{V}_{\boldsymbol{L}}{ }^{4} \\
\left(\mathrm{mln} . \mathrm{m}^{3}\right)\end{array}$ \\
\hline Ulken Shabakty & $18.04^{1}$ & $150^{2}$ & $8.15^{2}(3.15)^{1 * *}$ & $25^{1}$ & $8.68^{1}$ & $166.01^{1}$ \\
Burabay & $10.00^{1}$ & $164^{2}$ & $16.4^{1}$ & $5.4^{1}$ & $3.14^{1}$ & $31.33^{1}$ \\
Shortandy & $14.70^{1}$ & $70^{2}$ & $4.76^{1}$ & $22.2^{1}$ & $11.85^{1}$ & $179.35^{1}$ \\
\hline
\end{tabular}

Data sources: ${ }^{1}$ this study, ${ }^{2}$ Yapiyev et al. (2017b). ${ }^{3}$ Based on remote sensing data from 1986 to 2016 (inferred from mean long-term lake volume and area); ${ }^{4}$ Obtained from the analysis presented in this paper, for 2016; *The catchment surface area does not include the lake area; **This ratio is based on a reduced catchment area (see the caption of Fig. 1, and further explanation in Section 4.4). 

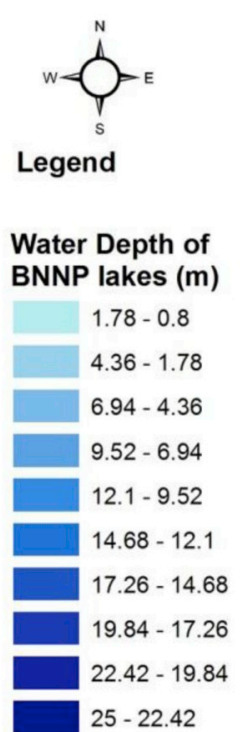

Elevation ( $\mathrm{m}$ )

\begin{tabular}{|c|}
\hline $290-338$ \\
\hline $338-389$ \\
\hline $389-438$ \\
\hline $438-498$ \\
\hline $498-581$ \\
\hline $581-693$ \\
\hline $693-921$ \\
\hline
\end{tabular}

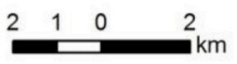

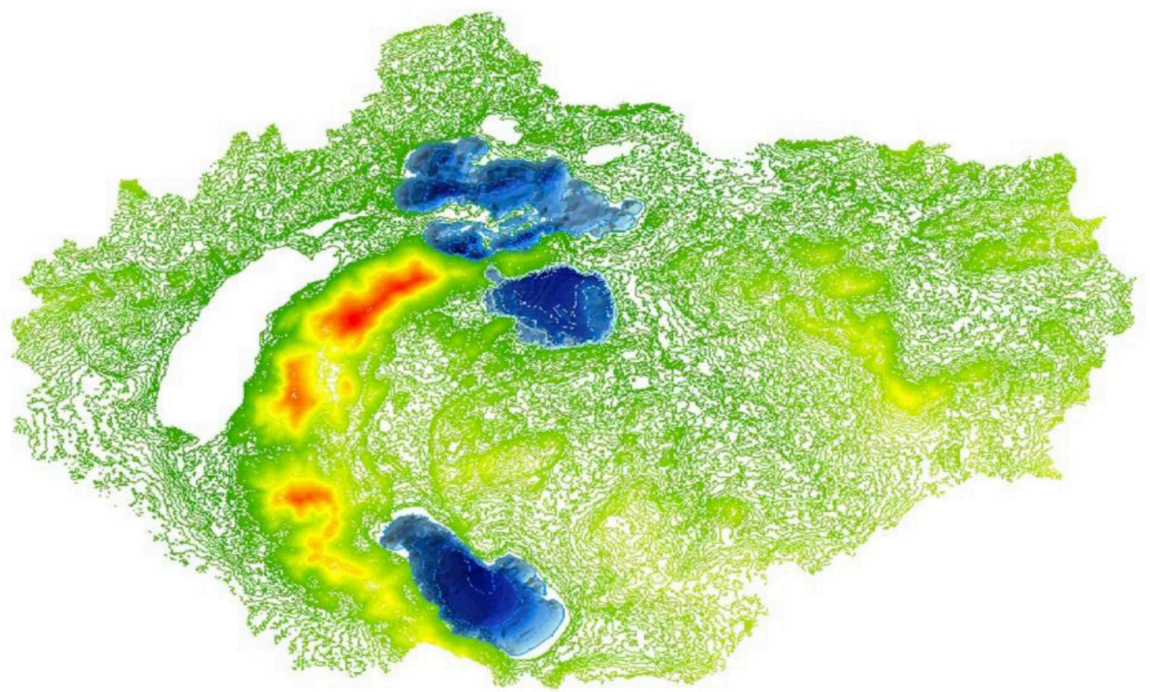

(a)

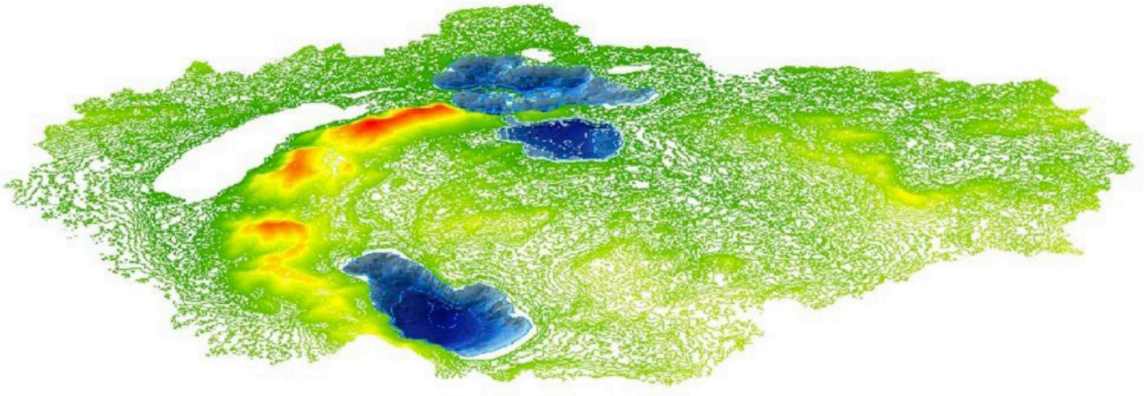

(b)

(c)

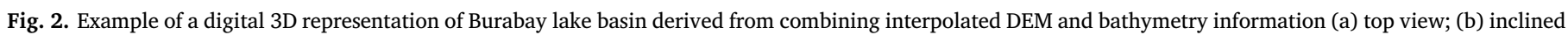
view (3D elevation); (c) side view (elevation profile).

areas of the 11 lakes - Ulken Shabakty, Kishi Shabakty, Shortandy, Burabay, Akkol, Zhaynak, Maybalyk, Tekekol, Gornoe, Karasie, and Svetloe - were calculated in ArcGIS from each yearly image.

Next, these vector polygons (using ArcGIS's Polygon Volume tool) together with the bathymetry model (Section 3.1.1) were used to estimate the volume (water storage) for Shortandy, Ulken Shabakty, and Burabay lakes on an annual basis (except for 1997-1998).

\subsection{Hydrometeorological and climate data}

\subsubsection{Lake water levels, lake temperatures and climate data}

Historical hydrometeorological observations were obtained from Kazhydromet (2017). Kazhydromet has three hydrometeorological stations in BNNP (see red symbols in Fig. 1) with different monitoring programmes. For the analysis of long-term climate trends, monthly precipitation $(P)$ and air temperature $\left(T_{a}\right)$ data from Shuchinsk weather station (Fig. 1) from 1935 to 2016 were used. Apart from standard hydrometeorological observations, Kazhydromet monitors lake water levels and lake surface water temperatures $\left(T_{w}\right)$ for lakes Burabay, Shortandy and Ulken Shabakty. Measurements are taken twice daily at 08:00 and 20:00 (the temperature is recorded only during the ice-free period) at $1 \mathrm{~m}$ from the shore edge at a depth of $0.1 \mathrm{~m}$. Monthly averaged lake surface water temperature data were available for the following time periods: Shortandy from 1980 to 2019 (gaps: 1998-2003), Burabay from 1980 to 2016 (gaps: 1998-1999) and Ulken Shabakty from 1985 to 2016 (gaps: 1994-2006).
Historical meteorological data were required to assess the long-term climate and water balance in BNNP. For evaporation assessment (see Section 3.5.2), we required monthly potential evapotranspiration $(P E T)$, precipitation $(P)$, wind speed at $10 \mathrm{~m}\left(U_{10}\right)$, and dew point temperature $\left(T_{d}\right)$ to calculate actual vapor pressure $\left(e_{a}\right.$, see Eq. (4)). We used monthly PET and $P$ from CRU (high-resolution (0.5 ); CRU TS v. 3.25) between 1986 and 2016 (Harris et al., 2014) and monthly $U_{10}$ and $T_{d}$ from a global atmospheric reanalysis (ERA-Interim with $0.75^{\circ}$ gridbox resolution) from 1986 to 2016 (Dee et al., 2011). CRU's PET is based on the Penman-Monteith grass reference evapotranspiration equation (Harris et al., 2014).

Monthly data for each variable were downloaded as NetCDF files. Point data for BNNP (coordinates: $52.75^{\circ} \mathrm{N}, 70.25^{\circ} \mathrm{E}$ ) were extracted in $\mathrm{R}$ (Rstudio, Inc, software version 1.0) using rgdal, raster, ncdf4 packages. CRU's PET data are daily for a given month, so the daily value was multiplied by the number of days in the month and summed as annual totals.

\subsubsection{Pan evaporation data}

For comparing our lake evaporation estimates (see Section 3.5.1), we used pan evaporation, $E_{P}$, measurements from Kazhydromet obtained at two stations that were closest to BNNP. These pans are USSR GGI-3000 type: a cylindrical tank with a diameter of $0.618 \mathrm{~m}$ and a depth of $0.6 \mathrm{~m}$, buried into the ground with walls protruding $75 \mathrm{~mm}$ above the land surface (Finch and Calver, 2008). The average distance of the pans to BNNP was about $400 \mathrm{~km}$ : 1) Kushmurum evaporation 


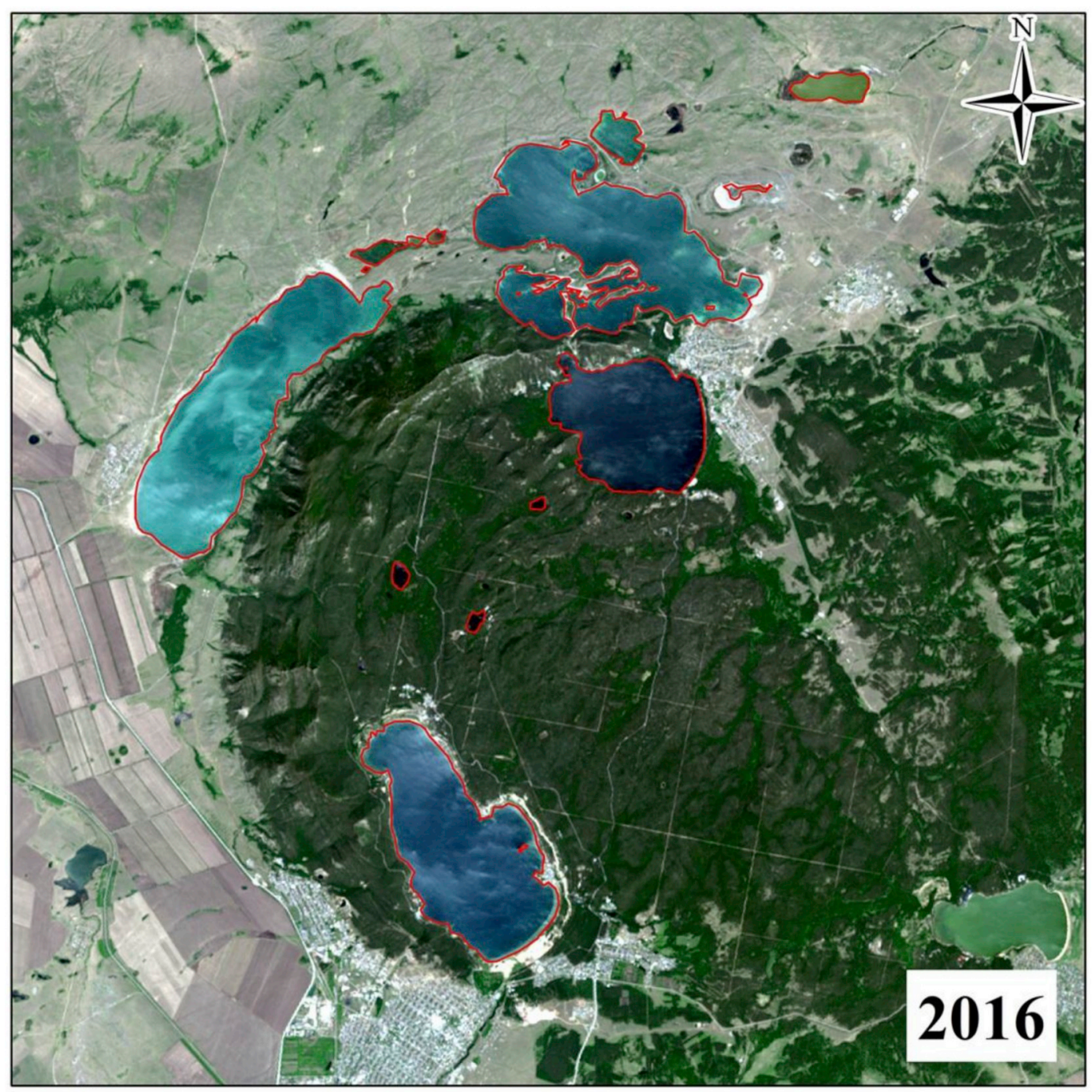

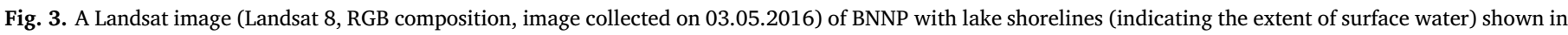

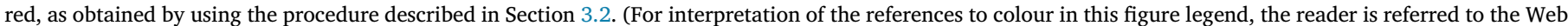
version of this article.)

pan, located to the west of BNNP $\left(52^{\circ} 27^{\prime} 16.00^{\prime \prime} \mathrm{N}, 64^{\circ} 35^{\prime} 35.00^{\prime \prime} \mathrm{E}, 109\right.$ msl) and 2) Bayanaul evaporation pan, located to the south-east of BNNP $\left(50^{\circ} 47^{\prime} 60.00^{\prime \prime} \mathrm{N}, 75^{\circ} 42^{\prime} 0.00^{\prime \prime} \mathrm{E}, 465 \mathrm{msl}\right)$. The evaporation pans are located in rural areas. We employed a commonly used pan-to-lake evaporation coefficient of 0.7 (Finch and Calver, 2008; McJannet et al., 2017; Xiao et al., 2018) to make the annual $E_{P}$ values comparable to the lake evaporation estimates obtained from the meteorological method described in Section 3.5.1.

\subsection{Statistical and climate data analysis}

Simple linear regression (SLR) and a two-sample two tailed $t$-Test (assuming equal variance) were used for the time series analysis with a significance level of $\alpha=0.05$. We report slope (change per year), regression coefficient $R^{2}$ (coefficient of determination), Pearson's $r$ (correlation coefficient) and p-value (the null-hypothesis is rejected or statistical significance is assumed if $\mathrm{p} \leq \alpha$ ) where applicable (Helsel and Hirsch, 2002).

For climate data time-series analysis (annual and seasonal) we also used a non-parametric Mann-Kendall (MK) test (Kendall, 1975) to identify significance of monotonic trends with significance level $\alpha=0.05$ and Sen's estimator (Sen's slope) that uses medians of the slopes instead of means (Helsel and Hirsch, 2002; Sen, 1968). Here
Kendall rank correlation coefficient (Kendall's tau) with $p$-value and Sen's slope are reported in addition to simple linear regression's $R^{2} . M K$ and Sen's estimator are insensitive to outliers and extensively used in hydrometeorological time-series analysis (Helsel and Hirsch, 2002). Statistical analysis was performed in Microsoft Excel (version 14.07.7208.500) and R (Rstudio, Inc, software version 1.0). For climate data analysis the zyp package (Bronaugh and Werner, 2013) and base $\mathrm{R}$ were used.

\subsection{Water balance components calculation}

The water balance equation of a lake can be expressed as:

$\Delta S=P_{L}+W_{y}-Q-E_{L}-A_{W}$

where $\Delta S$ is change in lake water storage, $P_{L}$ - precipitation over the lake, $W_{y}$ - catchment water yield (surface and groundwater inflow to the lake; this term summarises how much water the lake gained from precipitation falling on the catchment land area, $P_{\mathrm{C}}, Q$ - water from the lake contributing to the catchment storage via surface or groundwater flow, $E_{\mathrm{L}}-$ lake evaporation, and $A_{W}$ - anthropogenic water abstraction per catchment land area (Bennett et al., 2008). All water budget components in Eq. (1) are reported in $\mathrm{mm}$ water layer per year $\left(\mathrm{mm}\right.$ year $\left.{ }^{-1}\right)$ if not otherwise indicated. 


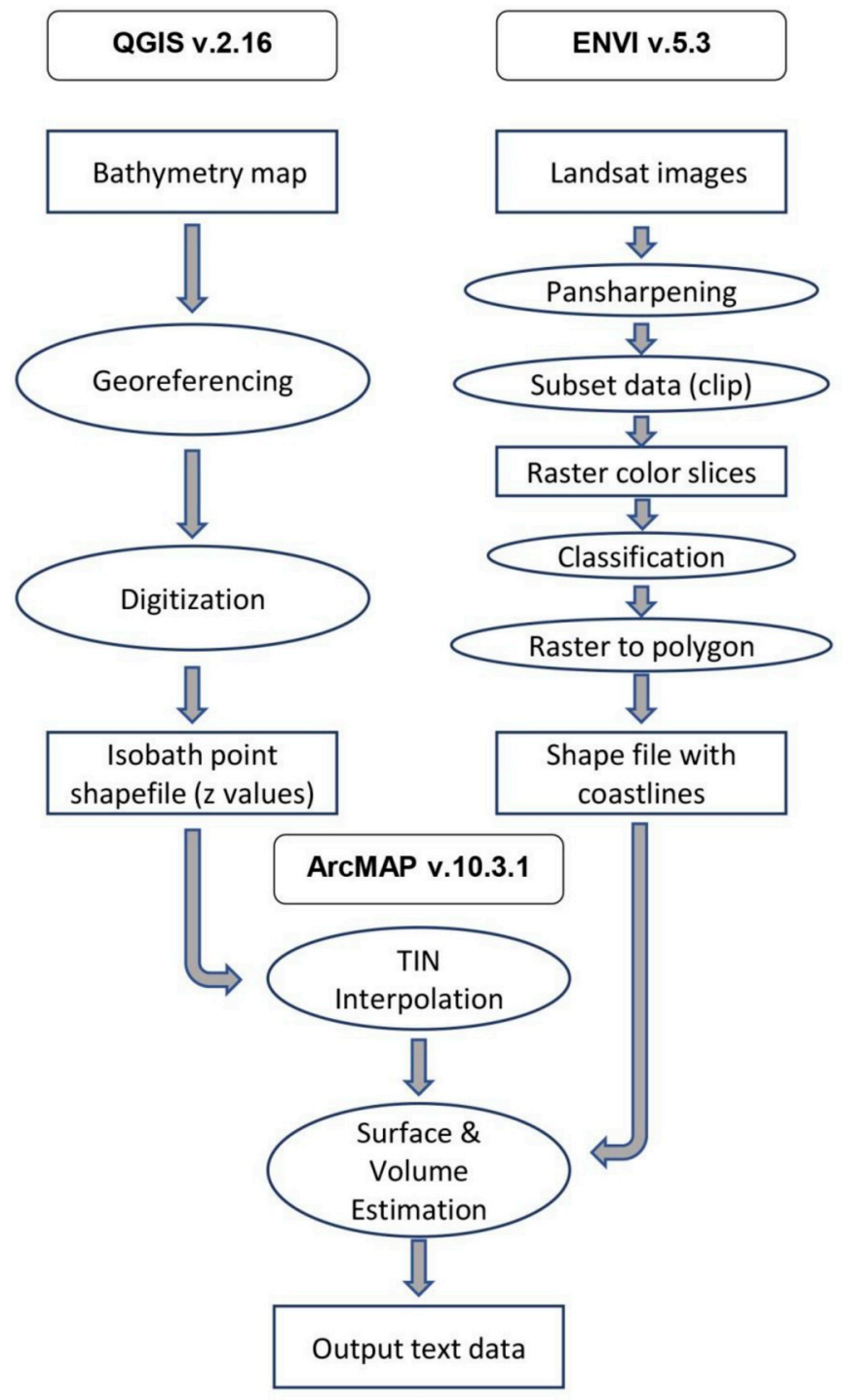

Fig. 4. Flowchart of remote sensing and GIS data processing and methods used in this research.

\subsubsection{Lake evaporation model}

Lake evaporation, $E_{L}$ in Eq. (1), is generally the single largest loss term in the water budget of endorheic lakes, including those in BNNP (Yapiyev et al., 2017b); therefore, it is considered in detail.

We employed a Dalton-type mass transfer method, which uses an empirical wind function (Harbeck, 1962; McJannet et al., 2012), to calculate lake evaporation:

$E_{L}=\left(2.909 \times U_{2}\right) \times S A_{L}^{-0.05} \times\left(e_{w}-e_{a}\right)$

Here, $E_{L}$ is the open water (lake) evaporation (mm day ${ }^{-1}$ ), $U_{2}$ is the wind speed at $2 \mathrm{~m}\left(\mathrm{~m} \mathrm{~s}^{-1}\right), S A_{L}$ is lake surface area $\left(\mathrm{m}^{2}\right), e_{w}$ is the saturation vapor pressure $(\mathrm{kPa})$ at water surface temperature, $T_{w}$, and $e_{a}$ is the actual vapor pressure $(\mathrm{kPa})$ at air temperature. The saturation vapor pressure $\left(e_{w}\right)$ and the actual vapor pressure $\left(e_{a}\right)$ are estimated from the monthly measured lake surface water temperature $\left(T_{w}\right)$ (see Section 3.3.1), and monthly dew point temperature $\left(T_{d}\right)$, from ERA-Interim, respectively, using:

$e_{w}=0.6108 \times \exp \left[\frac{17.27 \times T_{w}}{T_{w}+237.3}\right]$

$e_{a}=0.611 \times 10\left[\frac{7.5 \times T_{d}}{T_{d}+237.3}\right]$
A simple and widely applied scaling law was used to convert $U_{10}$ to $U_{2}$ (Milly and Dunne, 2016):

$U_{2}=0.75 \times U_{10}$

$S A_{L}$ for each lake and year is based on our Landsat image estimates (see Section 3.2). For the years with missing lake surface area data (1997 and 1998) we used the estimate for 1996.

\subsubsection{Budyko curve and actual evapotranspiration for BNNP catchment} area

For the assessment of climate controls in the BNNP catchments, we used the Budyko curve in terms of $P$-E. The well-established Budyko framework is widely used in catchment hydrology to assess the longterm annual catchment water balance (McMahon et al., 2013; Roderick et al., 2014). We applied Budyko's curve, using a standard formulation for the aridity index as proposed by Budyko (Budyko, 1974; McMahon et al., 2013) to infer annual actual catchment evapotranspiration, $A E T$ $\left(\mathrm{mm}\right.$ year $\left.^{-1}\right)$ :

$A E T=P_{C} \times F(\varphi)$

$P_{C}$ is the annual catchment precipitation for a given year $\left(\mathrm{mm} \mathrm{year}^{-1}\right)$, $\varphi$ is the aridity index defined as the ratio $P E T / P_{C}$, and $F(\varphi)$ is the Budyko function:

$F(\varphi)=\left\{\varphi[1-\exp (-\varphi)] \tan \left(\varphi^{-1}\right)\right\}^{1 / 2}$

PET and $P_{C}$ data from CRU (see Section 3.3.1) from 1986 to 2016 were used to calculate the aridity index.

\subsubsection{Water abstraction}

Finally, we estimated anthropogenic water abstraction in the watersheds of Burabay, Shortandy and Ulken Shabakty Lakes. The water abstraction data were taken from Kazhydromet's latest report on the water balance in BNNP (KazHydromet, 2014) and from the Esil Basin Inspection body for regulation of use and protection of water resources, which is responsible for water accounting in BNNP. The water abstraction data were available from 2000 to 2013. The water use data for Ulken Shabakty were combined with those for the smaller adjacent watershed of Tekekol Lake (as they are reported together) (Fig. 1).

To estimate the proportion of water abstraction with regards to its effect on the water balance of these lakes, we calculated the following annual abstraction components: (1) volume of abstracted water in the catchment plus the directly abstracted water volume from the lake, $V_{A}$, relative to its lake volume, $V_{L}$, expressed as a percentage (Eq. (8)), and (2) in $\mathrm{mm} /$ year for the catchment land area (Eq. (9)), which is equivalent to $A_{W}$ in Eq. (1):

$V_{A \%}=\left(V_{A} / V_{L}\right)$

$A_{W}=V_{A} / S A_{C}$

\subsubsection{Long-term lake water balance}

Endorheic lakes have no outlet and all surplus water in the catchment eventually ends up in the lake. This assumption is valid for all BNNP lakes considered in this study apart from Burabay Lake that behaves like a throughflow lake with its single outlet (a small river called Gromotukha) flowing into Ulken Shabakty Lake watershed. Changes in lake level or volume defines water storage change $(\Delta S)$ for the lakes, assuming long-term soil water storage is constant. For BNNP lakes $Q$ and $W_{y}$ terms (see Eq. (1)) are dominated by shallow groundwater fluxes (Yapiyev et al., 2017b). Stable water isotope data collected for the lakes (unpublished results), as well as a detailed energy and water balance analysis on a daily timescale (unpublished results (Yapiyev et al., 2018)) suggest that BNNP lakes are fed mostly from their catchments through shallow groundwater flow and that deep groundwater recharge is negligible for most of the years.

We calculated the long-term water balance separately for each lake 
(see Ireson et al., 2015) as currently we do not have information on the year-to-year groundwater flow. To obtain the long-term mean (1986-2016) annual watershed derived inflow $\left(\overline{W_{y}}\right)$ for each lake (Ulken Shabakty, Burabay and Shortandy Lakes) we subtracted (Section 3.5.2) from long-term $\bar{P}$ (obtained from CRU, see Section 3.3.1) then multiplied it by $r_{S A}$ (see Table 1), (Bennett et al., 2008). Thus Eq. (1) can be reformulated as:

$\overline{\Delta S}=\overline{P_{L}}+\overline{W_{y}}-\bar{G}-\overline{E_{L}}-\overline{A_{W}}$

where $\bar{G}$ is the long-term storage change due to recharge to deep groundwater (confined aquifer), and $\overline{E_{L}}$ is the long-term average lake evaporation (see Section 3.5.1).

By summing long-term $\overline{P_{L}}$ and $\overline{W_{y}}$ we obtained Total Inflow to the lake. Total Outflow/Loss was obtained by summing $\overline{E_{L}}$ and $\overline{A_{W}}$. The difference between Total Inflow and Outflow provided an estimate of long-term $\overline{\Delta S}$ plus $\bar{G}$.

\section{Results and discussion}

\subsection{Accuracy of lake area estimations by remote sensing}

The comparison of Landsat-based lake surface area, $S A_{L}$, estimates with those obtained with a higher resolution image (KazEOSat-2) is presented in Table 2. The percentage difference between the two estimates is very small ( $<1.4 \%$ of lake area) in particular for Lake Burabay, the smallest of the three lakes that were considered for this comparison.

In addition to the verification of our lake area estimates from Landsat by the higher resolution KazEOSat-2image, the accuracy of our lake area estimates is also corroborated by the fact that we detected the disappearance of Akkol Lake in 2012 (see Fig. 5c), as verified by ground observations.

Accuracy of lake area estimation from Landsat satellite imagery is generally good. For example, Xu (2006) reported an overall accuracy of $99.85 \%$ in the extraction of surface water body extent using Landsat images, and Klein et al. (2014) achieved a maximum accuracy of $94 \%$ (83\% overall) using AVHRR's imagery (with a spatial resolution of $1.1 \mathrm{~km}$ ) that had been benchmarked with Landsat images (with a spatial resolution of $30 \mathrm{~m}$ ).

Our findings compare well with the accuracy values quoted in these studies. This illustrates that free medium-resolution satellite imagery such as Landsat can be used successfully to monitor long-term changes in lake areal extent (and hence volume (see Section 4.2), assuming accurate bathymetry data are available), even for relatively small lakes, for example for local water resources impact assessment studies. Although there are uncertainties in our lake surface water area and volumes estimates, as the lakes are relatively small in size, we have used the best available high resolution remote sensing data with sufficiently long-term records to detect the changes in water storage.

The spatial resolution of $30 \mathrm{~m}$ that applies to Landsat and SRTM was considered high resolution until a few years ago. However, small-scale catchment studies ideally use sub-meter resolution remote sensing data (e.g. LIDAR) to accurately assess the water balance of small water bodies. Unfortunately, these ultra-high resolution data come at a significant cost and long-term records are not yet available. Hence, Landsat and similar data are still deemed to be useful and appropriate

Table 2

Comparison of lake surface area estimates based on Landsat- 8 and KazEOSat-2 images, for the ice-free period of 2016.

\begin{tabular}{llll}
\hline Lake & $S A_{L}, \mathrm{~km}^{2}$ (KazEOSat-2) & $S A_{L}, \mathrm{~km}^{2}$ (Landsat-8) & Difference \% \\
\hline Shortandy & 14.554 & 14.75 & 1.35 \\
Ulken Shabakty & 17.819 & 18.03 & 1.18 \\
Burabay & 9.985 & 9.96 & -0.25 \\
\hline
\end{tabular}

in many scientific and applied contexts, whether for water balance estimates or for the assessment of plant productivity/vegetation greenness, for example.

\subsection{Changes in lake surface area and water storage of BNNP lakes}

The changes in total BNNP lake surface area (for 11 lakes; as shown in Fig. 1) throughout the period 1986-2016 are presented in Fig. 5 (a, b, c).

Total $S A_{L}$ for the 11 BNNP lakes decreased from $67.5 \mathrm{~km}^{2}$ in 1986 to $62.9 \mathrm{~km}^{2}$ in 2016 (a reduction of $4.6 \mathrm{~km}^{2}$ or $\sim 7 \%$ of the total area), see Fig. 5a. This surface water area change is predominantly due to the decrease in areal extent of three lakes: Ulken Shabakty, Kishi Shabakty and Shortandy (a reduction of $4.8 \mathrm{~km}^{2}$; Fig. 5b). This decrease was partially compensated for by the increase in $S A_{L}$ of the smaller lakes (with an area of $1.5 \mathrm{~km}^{2}$ or less) in BNNP since 1986 (Fig. 5c). This increase is evident for the steppe lakes (Zhainak, Tekekol, Maybalyk) as well as the forest lakes (Gornoe, Karasie, Svetloe). $S A_{L}$ of the larger Burabay Lake had also slightly increased from $9.64 \mathrm{~km}^{2}$ to $10.00 \mathrm{~km}$ (see Fig. 5b).

As the main lakes are of tectonic origin and have deep basins, we also show $V_{L}$ for the three main lakes combined (see Fig. 5d) which display a similar downward trend $\left(\mathrm{R}^{2}=0.59\right)$ as that observed in Fig. 5a $\left(\mathrm{R}^{2}=0.57\right)$.

Total $V_{L}$ of the three main lakes (Ulken Shabakty, Shortandy \& Burabay) changed from $383.3 \mathrm{mln} . \mathrm{m}^{3}$ in 1986 to $376.7 \mathrm{mln} . \mathrm{m}^{3}$ in 2016 (a reduction of $6.6 \mathrm{mln} . \mathrm{m}^{3}$ or $1.7 \%$ ). This change in $V_{L}$ is due to the reduction of Ulken Shabakty Lake by $\sim 3.8 \mathrm{mln} . \mathrm{m}^{3}(2.3 \%$ decrease), and Shortandy Lake by $\sim 3.4 \mathrm{mln} . \mathrm{m}^{3}$ (1.9\% decrease), a reduction of $7.2 \mathrm{mln} . \mathrm{m}^{3}$ in total, while Burabay Lake's $V_{L}$ increased by 0.6 $\mathrm{mln} . \mathrm{m}^{3}(+2 \%)$. The increase in $V_{L}$ for Burabay Lake is partly caused by the fact that this lake is located in an area that receives higher rainfall amounts (Yapiyev et al., 2017b). Furthermore, this relatively modestly sized 'big' lake has a large catchment area (see Table 1, which shows that its catchment-to-lake ratio is two to four times larger than that of Ulken and Shortandy (the other two 'big' lakes) respectively.

The largest reductions in $S A_{L}$ and $V_{L}$ occurred in the following years: 1989, 1991, 1999-2000, 2004-2005, 2008, 2010 and 2012. These were years of particularly low rainfall and/or high evaporation (See Figs. 7 and 8). During a period of ten years (2006-2016) both lake area and volume stabilized, and they fluctuated approximately an average value of $63.6 \mathrm{~km}^{2}$ in terms of $S A_{L}$ and $377.3 \mathrm{mln} . \mathrm{m}^{3}$ in terms of $V_{L}$ (see Fig. 5).

Many endorheic lakes have shrunk considerably in both Central Asia and worldwide, posing a threat to fragile ecosystems and human populations (Bai et al., 2011; Yapiyev et al., 2017a). The largest BNNP lakes have been experiencing a decline for the past 100 years with the highest water level drops reported for Shortandy (19 m) and Ulken Shabakty (12 m) lakes (Yapiyev et al., 2017b).

Zhang et al. (2011) used a similar methodology to estimate water storage changes at Nam Co Lake in the central Tibetan Plateau using available remote sensing images from 1976 to 2009, bathymetry data and GIS tools. They found in fact an increase in this closed lake's surface area and water storage (due to increased precipitation, and surface runoff from the melting glaciers). This trend for the lakes on the Tibetan Plateau was confirmed by other independent studies using remote sensing (Donchyts et al., 2016; Pekel et al., 2016). This illustrates that trend analyses of climate data and key water balance components are required to explain the impact of these factors on lake levels, extent and volumes. In addition, quantification of the effects of anthropogenic water abstraction is needed. These aspects are covered below for the case of BNNP.

\subsection{Long-term trends in key climate variables}

We analysed changes in $P$ and $T_{a}$ from 1935 to 2016 across years and 


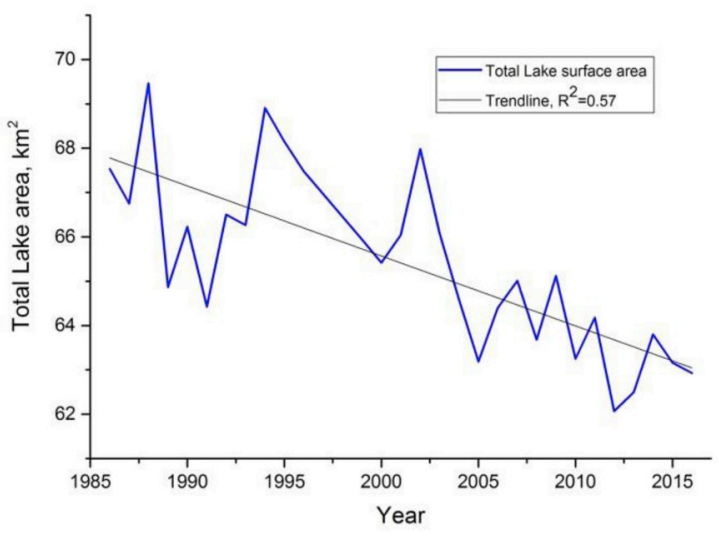

(a)

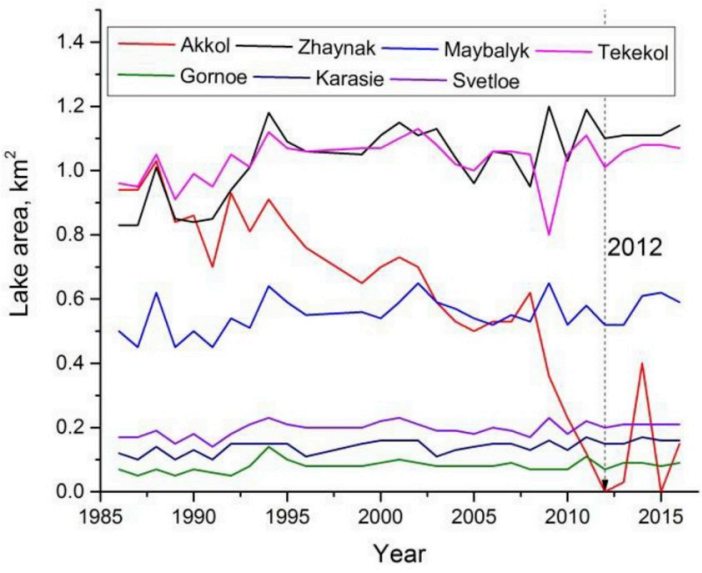

(c)

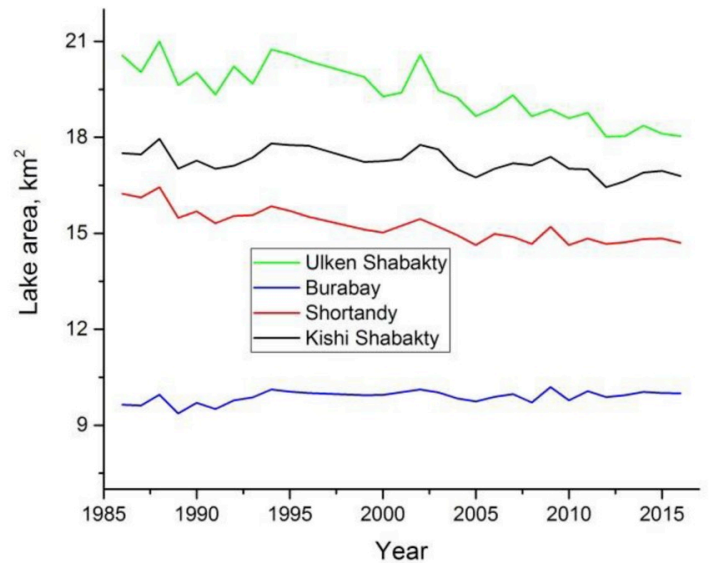

(b)

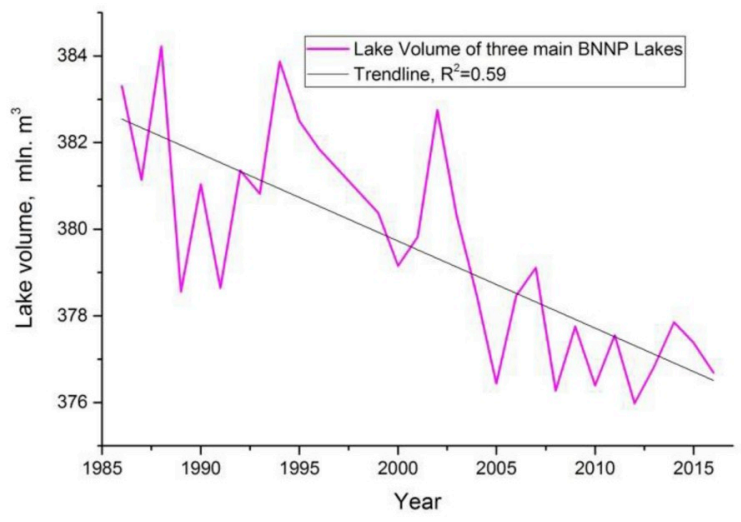

(d)

Fig. 5. The change in lake surface area, $S A_{L}$, and volume, $V_{L}$, of BNNP lakes between 1986 and 2016 (a) The change in total $S A_{L}$ of the 11 BNNP lakes: Ulken Shabakty, Kishi Shabakty, Shortandy, Burabay, Akkol, Zhaynak, Maybalyk, Tekekol, Gornoe, Karasie, Svetloe, (see Fig. 1 for location of the lakes); (b) The change in $S A_{L}$ for each of the 4 'big' BNNP lakes: Ulken Shabakty, Kishi Shabakty, Shortandy, Burabay; (c) The change in $S A_{L}$ for each of the 7 'small' BNNP lakes: Akkol, Zhaynak, Maybalyk, Tekekol, Gornoe, Karasie, Svetloe (vertical dashed line showing the temporary disappearance of surface water in Akkol lake in 2012, confirmed by ground observations); (d) The change in total $V_{L}$ of the 3 main BNNP lakes combined (Ulken Shabakty, Shortandy and Burabay), see Fig. 2 (3D representation of Burabay basin as an example of BNNP basins) and related text for the methodology used.

the climatological seasons, which are DJF (December, January, February - winter), MAM (March, April, May - spring), and JJA (June, July, August - summer) and SON (September, October, November autumn) in BNNP (Fig. 6 and Table 3).

Throughout the study period, there is a statistically significant increase in annual, spring and autumn $T_{a}$ (Table 3). Seasonally, the warming is most notable in autumn (Sen's slope $=0.0489^{\circ} \mathrm{C}$ /year, Kendall's tau $=0.394)$. There are no statistically significant trends in $P$ (Fig. 6, bottom row, and Table 3). However, there is a slight increase in winter precipitation (SLR's slope $=0.1171^{\circ} \mathrm{C}$ /year) and a slight decrease in autumn $P$ (SLR's slope $=-0.1065^{\circ} \mathrm{C} /$ year). However, overall, the long-term historical observations of precipitation in BNNP do not exhibit a significant trend (see also Yapiyev et al., 2017b).

Recently, Chen et al. (2018) reported that there is no spatially uniform trend in precipitation in the Central Asia domain for the 1960 to 2015 period. Mannig et al. (2013) used a regional climate model to make projections of climate change in Central Asia. They predicted a higher warming over most of the domain compared to the global average. With regards to precipitation rates, their dynamic downscaling of global circulation models projected a decrease in summer and an increase in winter in Northern Central Asia and the Tarim Basin (Mannig et al., 2013). The increase in winter precipitation fits with our observations.

\subsection{Precipitation, lake and pan evaporation and water balance}

\subsubsection{Precipitation, PET and AET for catchment}

The Budyko curve allows inference of the maximum possible longterm $A E T$ for a catchment taking into account atmospheric demand $(P E T)$ and available water $(P)$ (see Section 3.5.2.) The Budyko curve analysis provided a mean thirty year (1986-2016) value of $303 \mathrm{~mm} \mathrm{year}^{-1}$ for BNNP. Annual AET varied between 221 and $399 \mathrm{~mm}$ year $^{-1}$ (Fig. 7, grey curve). Mean PET (from CRU) for the same period was $760 \mathrm{~mm}$ year $^{-1}$ (Fig. 7 , solid black horizontal line). The CRU and Shuchinsk weather station mean precipitation values were both $335 \mathrm{~mm}$ year $^{-1}$ on average, and showed a very good agreement throughout the period (Fig. 7, dashed and solid blue lines, respectively).

The years with the lowest $P$ are 1988, 1991, 1995, 2004, 2008, 2010, and 2012 (Shuchinsk precipitation: 181, 198, 205, 253, 258, 208 and $314 \mathrm{~mm}$, respectively; Fig. 7a); these years have the highest PET values (pink line in Fig. 7): 809, 889, 803, 826, 838, 911, $904 \mathrm{~mm}$ year $^{-1}$. The driest years are 1988, 1991 and 2010 when the Budyko dryness index (PET/P) had values of 3.43, 3.94 and 3.95 respectively. These years also have the highest $P-E_{L}$ difference (see Section 4.4.2.). The long-term evaporative index $(A E T / P)$ is 0.91 , which means that around $90 \%$ of the precipitation in BNNP catchments is lost through evapotranspiration. 

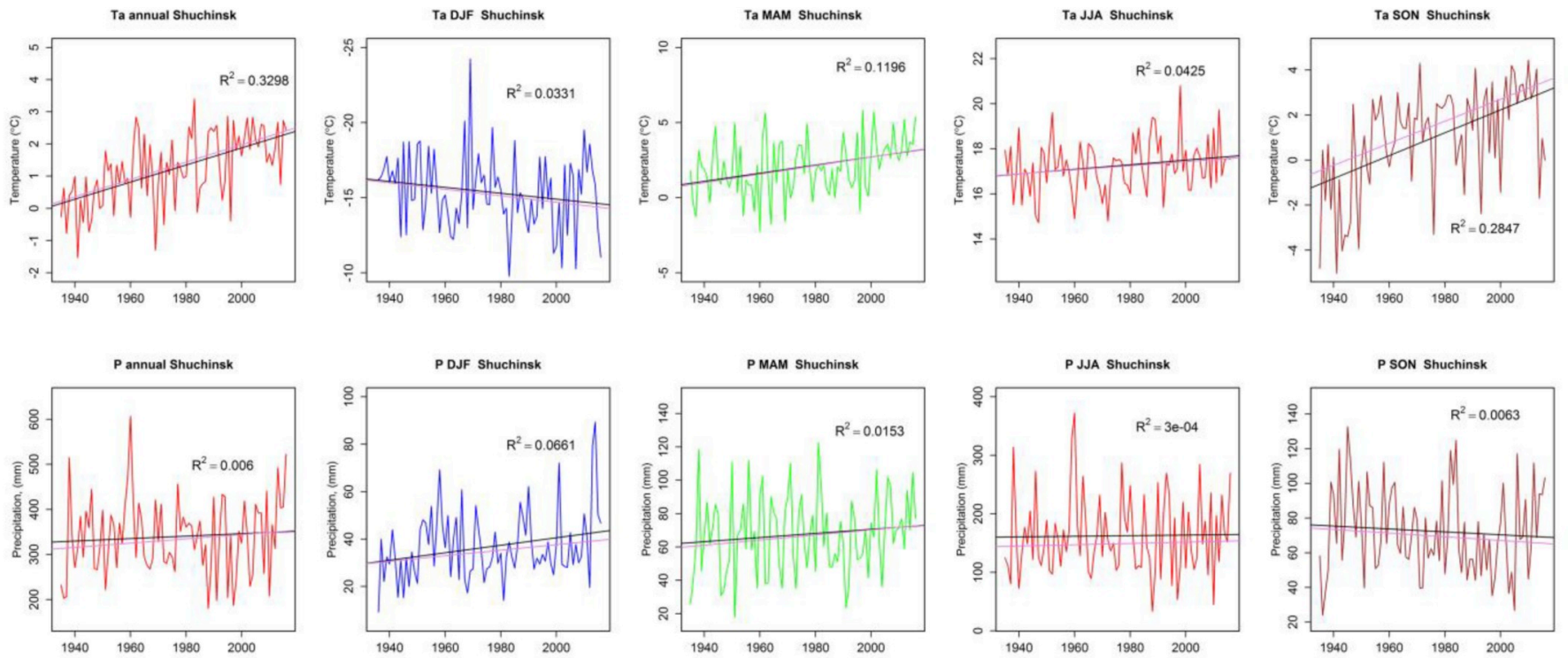

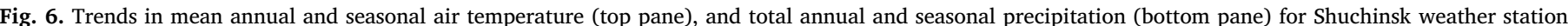

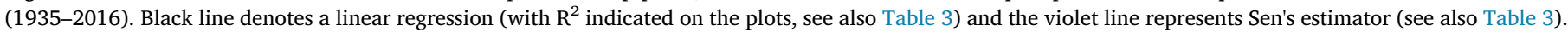
(For interpretation of the references to colour in this figure legend, the reader is referred to the Web version of this article.)

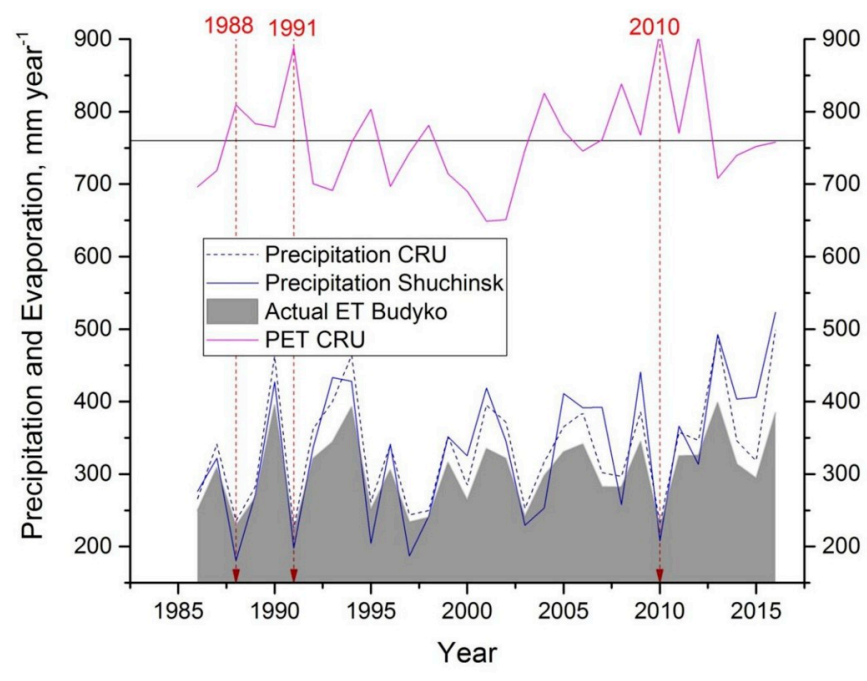

Fig. 7. Long-term precipitation and evaporation trends in BNNP. (a) Total annual precipitation from Shuchinsk weather station (see Fig. 1) and CRU (solid blue and dashed blue curves, respectively); potential evaporation (PET) from CRU data (pink solid line; horizontal black line denotes mean PET) and actual evapotranspiration (grey curve) for the BNNP area derived from Budyko' curve based on CRU's PET, and precipitation for the period of 1986-2016 (see Section 3.3.1 and 3.5.2). Red dashed vertical lines indicate driest years. (For interpretation of the references to colour in this figure legend, the reader is referred to the Web version of this article.)

\subsubsection{Lake and pan evaporation}

Annual $E_{L}$ values (calculated with Eq. (2); ice-free days only) for the same 30-year period, as shown in Fig. 7, for Burabay, Ulken Shabakty and Shortandy Lakes, are shown in Fig. 8 (solid lines), together with pan evaporation observations multiplied by the pan-to-lake coefficient of 0.7 (dashed lines).

Period-mean $E_{L}$ is highest ( $590 \mathrm{~mm}$ year $^{-1}$ ) for Burabay Lake (calculated for a period of 29 years), and 530 and $508 \mathrm{~mm} \mathrm{year}^{-1}$ for Ulken Shabakty and Shortandy Lakes (calculated for periods of 18 and 23 year durations, respectively. The discrepancies in the lengths of the timeseries of $E_{L}$ are caused by gaps in lake water temperature data, required to calculate $\left.E_{L}\right)$. Annual $E_{L}$ values vary between 399 and $821 \mathrm{~mm}$ year $^{-1}$ (minimum and maximum values, considering all three lakes).

$E_{L}$ for Burabay Lake is highest ( $>700 \mathrm{~mm} \mathrm{year}^{-1}$ ) in 1997, 2010 and 2012 amounting to 736,718 and $717 \mathrm{~mm}$ year $^{-1}$, respectively. $E_{L}$ for Ulken Shabakty Lake peaks in 2010, 2012, 2015 and 2016 totaling $651,612,593$ and $631 \mathrm{~mm}$ year $^{-1}$, respectively. The largest lake evaporation totals for Shortandy Lake are found in 1991, 1995, 1997, 2010 and 2012 reaching 609, 658,635, 623 and 581 mm year $^{-1}$, respectively. A number of these years are heatwave years in the region (e.g. 2010 and 2012), when dry and warm air masses increased $E_{L}$ because of higher $e_{\mathrm{a}}$ and $T_{\mathrm{w}}$ values (see Eqs. (2)-(4)), (Blunden et al., 2011; Blunden and Arndt, 2013; Guo et al., 2018).

Results of the statistical analysis for annual $E_{L}$ and $E_{P}$ totals are shown in Table 4. Overall, there is a good correspondence between $E_{L}$ and $E_{P}$, and the correlation is particularly strong between Ulken Shabakty $E_{L}$ and Kushmurun $E_{P}$ (see also Fig. 8). The difference between annual $E_{L}$ and $E_{P}$ totals is non-significant for all lakes (Table 4). The Kushmurun evaporation pan is located to the west of BNNP, and west to southwest is the dominant wind direction over BNNP. This pan is situated at a low elevation and set in a steppe environment which is similar to the surroundings of Ulken Shabakty Lake. The other two lakes are higher up and surrounded by forest. The Bayanaul pan is found to the southeast area of BNNP at a higher elevation $(\sim 500 \mathrm{msl})$ in a forested area similar to BNNP.

The years of highest $E_{L}$ broadly coincide with the years of highest PET (obtained from CRU data, See Fig. 7), specifically for the years 1991 (Shortandy Lake), 1995 (Burabay \& Shortandy Lakes), 2008 (Burabay Lake), 2010 (all lakes) and 2012 (all lakes). Some of these years are in fact those with the lowest AET (1991, 1995, and 2010), because the prolonged period of high atmospheric demand depleted the catchments' soil water resources. There is a significant correlation between BNNP catchment area PET for the ice-free period (April to October) and $E_{L}$ (Burabay: $r=0.60, \mathrm{p}=0.00056$; Shortandy Lake: $r=0.64, p=0.00106 ; r=0.52, p=0.02670$ for Ulken Shabakty, relationships not shown).

By considering the estimated mean annual $E_{L}$, we estimate the loss of water through evaporation for the 30-year study period as 18.8, 6.1 and $4.4 \%\left(0.18 \mathrm{mln} . \mathrm{m}^{3}, 0.31 \mathrm{mln} . \mathrm{m}^{3}\right.$, and $0.25 \mathrm{mln} . \mathrm{m}^{3}$ in water volume terms) of mean $V_{L}$ values for Burabay, Ulken Shabakty and 


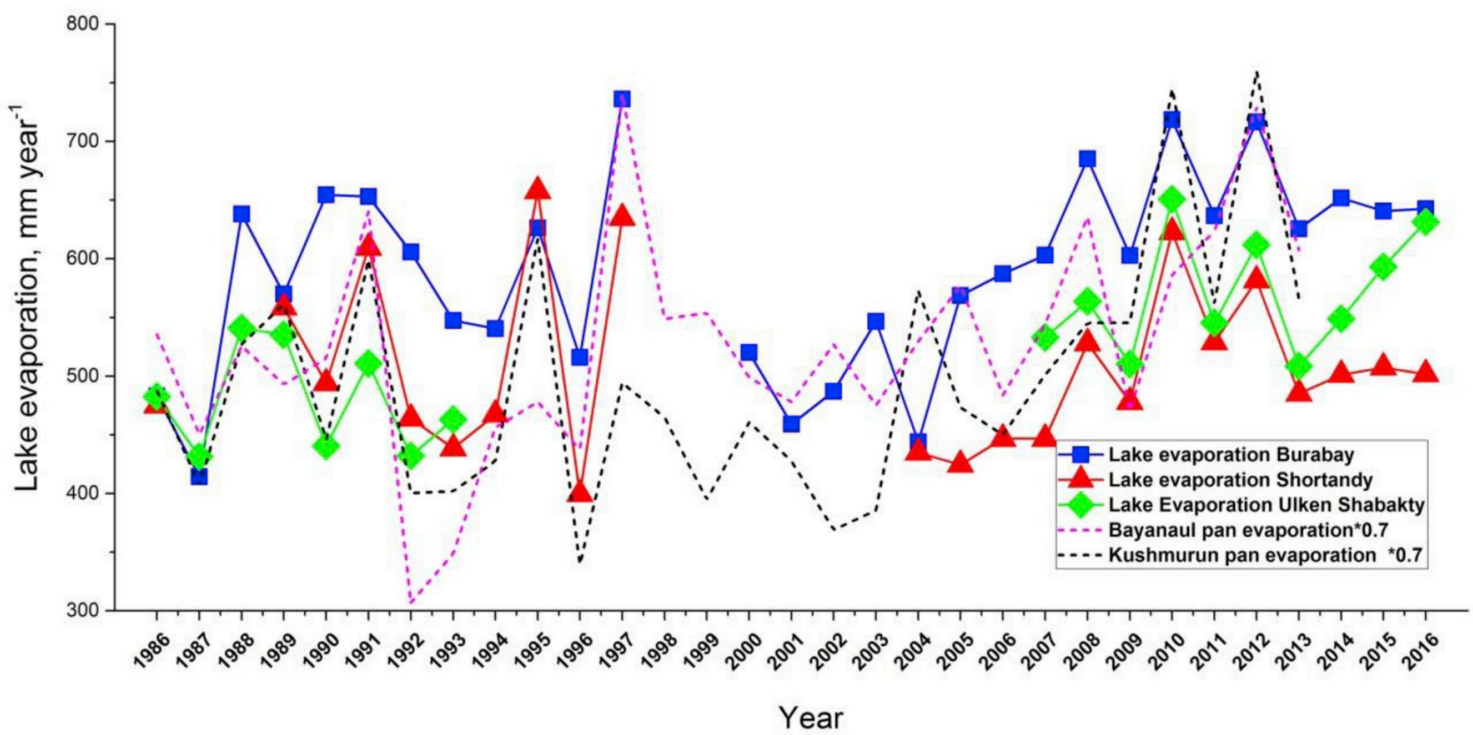

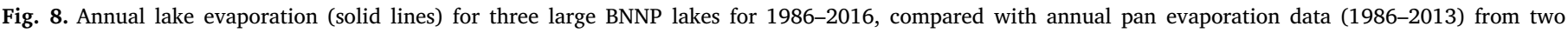
observation sites which are located approximately $400 \mathrm{~km}$ away (dashed lines. These were the closest pan evaporation data available).

Table 3

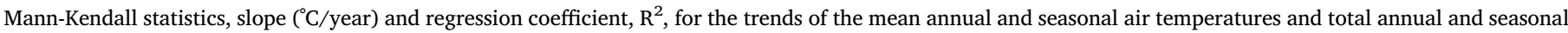

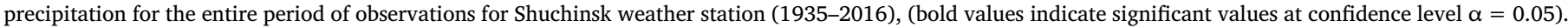

\begin{tabular}{|c|c|c|c|c|c|c|c|c|c|c|}
\hline \multirow[t]{2}{*}{ Parameter } & \multicolumn{5}{|c|}{ Air Temperature } & \multicolumn{5}{|c|}{ Precipitation } \\
\hline & Annual & DJF & MAM & JJA & SON & Annual & DJF & MAM & JJA & SON \\
\hline Kendall's tau & 0.4040 & 0.1130 & 0.2310 & 0.1050 & 0.3940 & 0.0732 & 0.0970 & 0.0955 & 0.0277 & -0.0654 \\
\hline p-value & 0.0000 & 0.1386 & 0.0024 & 0.1693 & 0.0000 & 0.2745 & 0.1578 & 0.1237 & 0.0513 & -0.0828 \\
\hline SLR's slope & 0.0266 & 0.0196 & 0.0271 & 0.0102 & 0.0508 & 0.0475 & 0.1171 & 0.1543 & 0.1094 & -0.1065 \\
\hline Sen's slope & 0.0269 & 0.0216 & 0.0284 & 0.0090 & 0.0489 & 0.0060 & 0.0661 & 0.0153 & 0.0003 & 0.0063 \\
\hline $\mathrm{R}^{2}$ & 0.3298 & 0.0331 & 0.1196 & 0.0425 & 0.2470 & 0.0060 & 0.0661 & 0.0153 & 0.0003 & 0.0063 \\
\hline
\end{tabular}

Table 4

Correlation coefficient $(r$ ) for the comparison between annual lake evaporation and pan evaporation (their compass direction in relation to BNNP is given between brackets), the latter with the pan-to-lake coefficient applied (bold values indicate significant values at confidence level $\alpha=0.05$, 2-tailed test of significance is used). For details see Data and Methods: Section 3.4).

\begin{tabular}{lllll}
\hline Lake/Pan & Kushmurun (W) & p-value & Bayanaul (SE) & p-value \\
\hline Burabay & $\mathbf{0 . 6 8}$ & 0.00012 & $\mathbf{0 . 6 1}$ & 0.02993 \\
Ulken Shabakty & $\mathbf{0 . 8 9}$ & 0.00001 & $\mathbf{0 . 6 6}$ & 0.00799 \\
Shortandy & $\mathbf{0 . 6 9}$ & 0.00072 & $\mathbf{0 . 5 3}$ & 0.01621 \\
\hline
\end{tabular}

Shortandy Lakes, respectively.

There is a good correlation between annual $E_{L}$ and $V_{L}$ for Ulken Shabakty Lake $(r=-0.71, p=0.00091)$, whereas there is negligible correlation for Burabay ( $r=0.11, p=0.56651)$ and Shortandy Lakes ( $r=-0.09, p=0.70549)$; data not shown. This is most probably caused by the fact that the water balance of Ulken Shabakty Lake is mostly controlled by open water evaporation (it behaves like an "evaporation pan"), while the water budgets for Burabay and Shortandy Lakes are also influenced by groundwater recharge and anthropogenic water abstraction (see next section).

The higher $E_{L}$ in Burabay Lake can be explained by its higher surface water temperatures, $T_{w}$ (data not shown), see Eqs. (2)-(4), caused by the fact that its lake volume is more than five times smaller than Shortandy and Ulken Shabakty Lakes, hence it will heat up more rapidly during the ice-free period. It is notable that after the last heatwave in $2012 E_{L}$ values of Burabay and Shortandy Lakes levelled off whereas $E_{L}$ of Ulken Shabakty Lake continued to increase (see Fig. 8). This increase can be explained by the influence of the advection of warm air from the steppe north to Ulken Shabakty.

\subsection{Anthropogenic water abstraction and the impact of anthropogenic activities on the water balance}

Fig. 9a shows that the water abstraction, $V_{A}$, for the watersheds of Burabay, Ulken Shabakty and Tekekol Lakes has remained relatively stable during (most of) the 14-year period from 2000 to 2013 (this is the only period for which water abstraction data are available). The water consumption in the Shortandy Lake watershed, where the largest settlement of Shuchinsk town is located, has been considerably more variable, and displayed a distinct drop after 2008, when direct water abstraction from the lakes was prohibited by state authorities. The relative amount of water used for human consumption, $V_{A \%}$, amounts to $1.6 \%$ at most of $V_{L}$ in Burabay Lake watershed and $1.3 \%$ for Shortandy Lake watershed (Fig. 9b), which has the largest $V_{A}$ values (Fig. 9a). $V_{A \%}$ for Ulken Shabakty Lake did not exceed 0.24\%, (Fig. 9b). This may partly explain the better correlation between $E_{L}$ and $\Delta V_{L}$, discussed in the previous section. Although direct water abstraction from the lakes was prohibited in 2008, the effect of this measure is not apparent from $V_{A}$ values shown in Fig. 9a for Burabay and Ulken Shabakty/Tekekol, whereas those for Shortandy indeed declined significantly after 2008.

Though under state protection, Burabay catchments are intensively influenced by anthropogenic activities (Yapiyev et al., 2017b). Although direct human influence, such as water abstraction in the lakes' watersheds are having a moderate or minimal impact on the lakes' water levels, indirect activities such as the construction of roads or hotels, and the expansion of settlements may have a larger effect on 


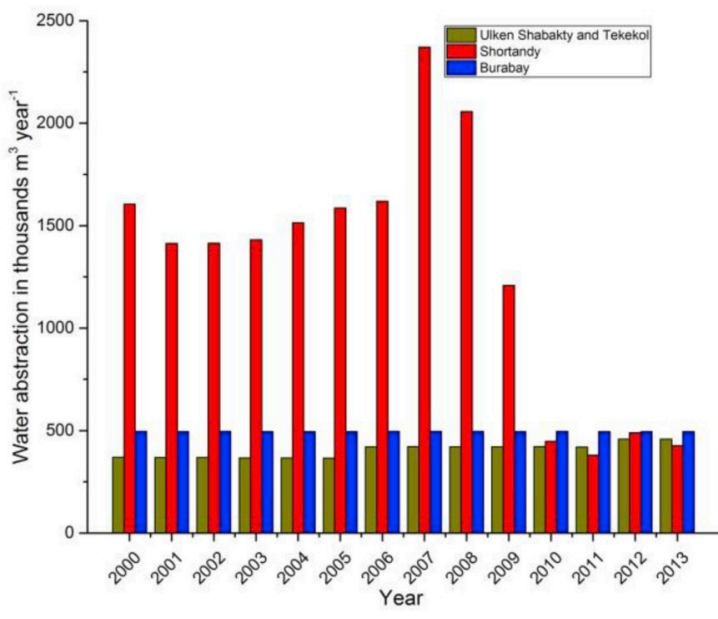

(a)

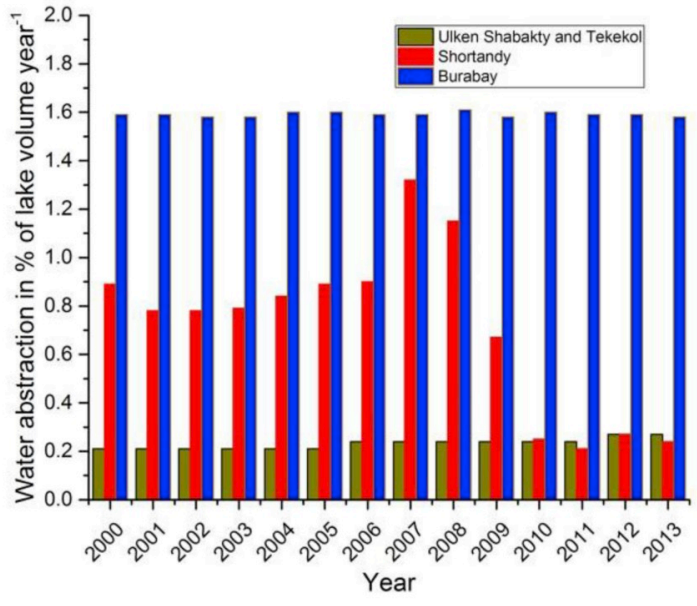

(b)

Fig. 9. Water abstraction, $V_{A}$, in three main watersheds in BNNP (2000-2013) (a) in thousands $\mathrm{m}^{3}$ year $^{-1}$, (b) in $\%$ of lake volume year ${ }^{-1}\left(V_{A \%}\right.$, see Eq. (8)) Lakes: Ulken Shabakty with Tekekol, Shortandy and Burabay.

lake water storage. The expansion of Burabay settlement in the catchment of Ulken Shabakty Lake caused the isolation of a large portion of the drainage basin of this lake (Fig. 1). Consequently, effective $S A_{C}$ now measures $56.8 \mathrm{~km}^{2}$ (the watershed/lake surface area ratio is $\approx 3.15$, instead of 8.15 if one takes the DEM delineated watershed area). The portion of the Ulken Shabakty watershed that has been isolated since the construction of the road (see Fig. 1, red line) is forested. This means that it can hold more snowfall during the cold period (that will melt in the spring and would have added to lake water volume via inflow of melted snow water). However, exact quantification of such impacts requires further investigation through detailed hydrological modelling, combined with information obtained from higher resolution remote sensing data.

Shaw et al. (2012) documented the influence of anthropogenic features such as culverts and roads on the extent and spatial distribution of watershed contributing area to run-off in Canada's prairie's wetland complexes. They used high-resolution DEM (1-m pixel size) and concluded that the roads act as a dam.

Finally, although the reduction of anthropogenic water abstraction in BNNP watersheds may be of moderate significance for the lakes' water balance (see Section 4.5), in particular for lakes Burabay and Ulken Shabakty, it could be beneficial for the local population as the lake waters have a very high fluoride level that has been increasing steadily over the past years (Yapiyev et al., 2017b). Excessive high fluoride levels affect human health, e.g. causes dental fluorosis.

\subsection{Long-term average lake water balance}

The annual long-term water balance components of three main
BNNP lakes are presented in Table 5. We compared these with reconstructed historical water levels (based on publicly available data) from our earlier work (Yapiyev et al., 2017b) to check our estimates. Yapiyev et al. (2017b) reported the following changes in lake levels from 2000 to 2015: a decrease of Ulken Shabakty and Shortandy Lakes by 1.6 and $0.4 \mathrm{~m}$, respectively, and an increase of Burabay Lake by $0.3 \mathrm{~m}$. Based on Table 5 the changes in water levels for the same period are as follows: an increase for Ulken Shabakty and Burabay Lakes of $0.71 \mathrm{~m}$ and $3.75 \mathrm{~m}$, respectively (the values are obtained by multiplying $\overline{\Delta S}$ by the total number of years; 16), and a decrease of Shortandy Lake by $0.59 \mathrm{~m}$ for the same period. However, if we take a reduced value of $r_{S A}$ (see description for Table 1 and 5, and Section 4.4) for Ulken Shabakty Lake we calculate a decrease in lake level of $1.65 \mathrm{~m}$ instead, which fits with the $1.6 \mathrm{~m}$ drop reported in the literature. This corroborates our hypothesis on the effective watershed surface area for this lake as discussed in the previous section.

We explain the large discrepancy between the previously published (increase of $0.3 \mathrm{~m}$ ) and the current water balance estimate for Burabay Lake (increase of $3.75 \mathrm{~m}$ ) by the following. The difference between $W_{y}$ and $\overline{\Delta S}$ is $275 \mathrm{~mm}$ year $^{-1}\left(525-250 \mathrm{~mm}\right.$ year $^{-1}$ ) which is partly discharged through its outlet into Ulken Shabakty' watershed, and partly percolates into deep groundwater. Moreover, most probably the pine forests extensively use the shallow groundwater for transpiration, and $A E T$ for this watershed will in reality be considerably higher than our long-term $\overline{A E T}$ estimate, especially in dry years. Our preliminary results on detailed estimates of the energy and water balance of BNNP lakes, using daily data (Yapiyev et al., 2018), identified an approximate deficit of $\sim 200 \mathrm{~mm}$ (unaccounted water loss term) in the water balance of Burabay Lake in the year 2010 when the precipitation was extremely

Table 5

Long-term averaged water balance components of major Lakes of Burabay National Nature Park during 1986-2016.

\begin{tabular}{|c|c|c|c|c|c|c|c|c|c|}
\hline Lake & $\begin{array}{l}\text { Precipitation, } P \\
\text { (mm/year) }\end{array}$ & $\begin{array}{l}\text { Lake } \\
\text { Evaporation, } E_{L} \\
\text { (mm/year) }\end{array}$ & $\begin{array}{l}\text { Catchment AET } \\
\text { (mm/year) }\end{array}$ & $\begin{array}{l}\text { Ratio } \\
\text { Watershed/ } \\
\text { Lake Area, } r_{S A}\end{array}$ & $\begin{array}{l}\text { Water Yield, } W_{\mathrm{y}} \\
(\mathrm{mm} / \text { year })^{\mathrm{b}}\end{array}$ & $\begin{array}{l}\text { Anthropogenic water } \\
\text { consumption, } A_{W} \\
\text { (mm/year) }\end{array}$ & $\begin{array}{l}\text { Total } \\
\text { Inflow, } \\
P+W_{\mathrm{y}} \\
\text { (mm/year) }\end{array}$ & $\begin{array}{l}\text { Total } \\
\text { Outflow/Loss, } \\
E_{L}-A_{W} \\
\text { (mm/year) }\end{array}$ & $\begin{array}{l}\text { Change in } \\
\text { Lake Storage, } \\
\Delta \mathrm{S} \text { (mm/year) }\end{array}$ \\
\hline Ulken Shabakty & 335 & 546 & 303 & $8.15(3.15)^{\mathrm{a}}$ & 261 (101) & 3 & 596 & 549 & $47(-113)^{\mathrm{a}}$ \\
\hline Burabay & 335 & 607 & 303 & 16.4 & 525 & 3 & 860 & 610 & 250 \\
\hline Shortandy & 335 & 508 & 303 & 4.76 & 152 & 18 & 487 & 526 & -39 \\
\hline
\end{tabular}

Note that ( $\bar{G}$ was assumed zero for Shortandy and Ulken).

a The estimate is based on reduced watershed area/lake area ratio, $r_{S A}$ (see Fig. 1 and Table 1, and further explanation in Section 4.4).

b $\bar{W}_{\mathrm{y}}=r_{S A}\left(P_{C}-A E T\right)$. 
low, especially during summer. This was because the pine forest accessed shallow groundwater when soil water stores were running low. Vincke and Thiry (2008) reported that Scots pine (Pinus sylvestris, the dominant tree species in BNNP) can almost solely rely on supply from the water table during summer drought as a source of water for transpiration when extractable soil water is minimal.

The fairly constant long-term water level/volume of Burabay Lake (see Fig. $5 \mathrm{~b}$ ) is determined not only by its smaller $V_{L}$ but also by the fact that it has a larger $S A_{C}$ which increases water harvesting via surface run-off and sub-surface recharge (Yapiyev et al., 2017b).

\subsection{General discussion}

The endorheic lakes in BNNP are regulated primarily by climate variability. Table 5 shows that the lake evaporation dominates the water budget of BNNP lakes, and the fact that lake evaporation has increased for a large part of the 2000-2013 period, has led to a steady decline of lake levels of Shortandy and Ulken Shabakty Lakes. During this period, air temperatures have increased (see Fig. 6, top row), which affects the lake temperatures and the vapor pressure difference between the lakes' surface and the atmosphere, a major driving force for lake evaporation. However, recent increases in precipitation (since 2012 or so, see Fig. 6, bottom row) have caused the lake levels to stabilize. After the last drought in 2012, the lake levels have been recovering due to higher than usual precipitation amounts.

Overall, lake water storage variations show that BNNP lake volumes have approximately been in equilibrium with climate conditions during the past decade (from 2006 to 2016). Our Budyko curve analysis shows that BNNP catchments are under water-limited conditions for most of the years. The increase in PET in the last decade signals the rising atmospheric demand and related higher lake evaporation rates. However, concurrent higher atmospheric $\mathrm{CO}_{2}$ levels can lead to increased water use efficiency of vegetation and related decrease in transpiration, and accordingly cause an increase in runoff from watersheds to the lakes (Jasechko, 2018). This effect can possibly explain the recent stabilisation and even increase of BNNP's lake water storage. This is partially supported by a recently published dendroclimatological study on BNNP where the authors (Kopabayeva et al., 2017) reported an increase in width of tree-rings since 1950-2015 particularly notable from 2006 onward. Kopabayeva et al. (2017) concluded that it is mostly due to an increase in local precipitation for the October-July period; however, our climatological analysis does not identify any statistically significant trends in $P$ for this period.

Watershed inflow to the lakes may be a significant gain term in the water balance of BNNP lakes during the years of considerable snowmelt (Yapiyev et al., 2017b), with groundwater predominantly feeding the lakes, as derived from stable water isotope analyses (unpublished results (Yapiyev et al., 2018)). This gain term is most significant for Burabay Lake (see Table 5).

\section{Conclusions}

We conducted a thirty-year analysis of changes in water storage of small endorheic lakes in semi-arid Northern Central Asia by combining remote sensing, ground measurements including bathymetric surveys and hydrometeorological observations, and gridded climate data (CRU and ERA Interim), utilizing GIS tools and micrometeorological equations to estimate evaporation losses to assess impacts of climate on lake storage. Furthermore, we assessed the effect of anthropogenic activities on BNNP endorheic lake storage by studying the water abstraction for the largest lakes in BNNP.

Our findings show that the water storage decline in BNNP lakes for those thirty years has been relatively modest. Shortandy and Ulken Shabakty water volumes have declined during the past three decades, but the volume reduction is only around $2 \%$. The surface area of some smaller lakes even increased.
The decline of BNNP lakes can be attributed to a long-term $P-E_{L}$ deficit, i.e. lake evaporation exceeding lake recharge by precipitation. There is a trend of rising air temperatures in BNNP that is expected to continue (see Yapiyev et al., 2017b) and this contributes to increased $E_{L}$. However, note that atmospheric vapor pressure and wind speed play the most important role in lake evaporation, as well as the intricate feedback between these atmospheric variables and lake surface temperature which is also an important driver of lake evaporation. We also identified that the long-term increase in $T_{a}$ for this region is significant in the spring and autumn. This means that the duration of the ice-free (open water) period is increasing, i.e. the length of the lake evaporation season will lengthen, which can further increase $E_{L}$.

Anthropogenic impact through water abstraction has played a small role in the BNNP lakes' water balance. However, human induced land use changes (construction of hotels and related roads, with the latter acting as 'dams') in the lakes' watersheds have negatively affected the recharge of the lakes. The two largest lakes (Ulken Shabakty and Shortandy), which show the highest historical water level declines, do not have a sufficiently large water drainage basin area to sustain water levels under current and future local evaporation rates.

Although the BNNP lakes' water volumes are currently relatively constant, the continuing increase in atmospheric demand, resulting in higher PET and lake evaporation rates, can lead to further deterioration of lake levels and the unique ecosystems of Burabay National Nature Park. Further work in BNNP must include a detailed investigation of the lateral interactions between lakes and groundwater, with a focus on the role of snowmelt. The groundwater recharge from snowmelt most likely plays a more significant role for Burabay and Shortandy Lakes located inside the Kokshetau ridge, while its effect is most probably minor for Ulken Shabakty and the other steppe lakes in most of the years. Another key knowledge gap is that of vegetation response, such as AET rates and carbon fluxes, to changing climate conditions. The present estimates of lake evaporation can be refined; therefore, we are currently analyzing high frequency BNNP data (including lake temperatures and evaporation), while taking into account the effects of lake surroundings, meteorological conditions, lake thermal behavior and heat storage.

In conclusion, high-resolution remote sensing data can help understand the water balance of endorheic lakes in particular, when combined with gridded climate data such as those available from CRU and global atmospheric reanalysis products, such as ERA Interim. Open water evaporation, unlike terrestrial actual evapotranspiration cannot be directly estimated from satellite data (McCabe et al., 2017). However, relatively accurate measurements of lake surface water temperatures can be obtained from satellites (Woolway and Merchant, 2017). The combination of such remote sensing measurements with ERA Interim data to drive mass transfer lake evaporation models would make lake evaporation assessment possible without having to rely on ground observations.

\section{Funding}

This research was supported under the target program No. 0115RK03041 "Research and development in the fields of energy efficiency and energy saving, renewable energy sources, and environmental protection for years 2014-2016" from the Ministry of Education and Science of the Republic of Kazakhstan. This research was partly supported under the target program No. BR05236529 "Complex ecosystem assessment of Shuchinsk-Borovoye resort area through the environmental pressure evaluation for the purposes of sustainable use of recreational potential" from the Ministry of Education and Science of the Republic of Kazakhstan. We also would like to acknowledge the support from the project, "Climate Change, Water Resources and Food Security in Kazakhstan" (CCKAZ) funded by the United Kingdom's Newton Fund Institutional Links Programme (Grant No. 172722855). This research was also supported by the National Natural Science Foundation of China (U1603242), the USAID PEER, UK Royal Academy 
of Engineering through the Industry Academia Partnership Program and Nazarbayev University. We also would like to thank engineer Vladimir Novokhatskiy for assistance in installation and maintenance of the equipment. We acknowledge the contributions from Anara Kassymbekova, Marzhan Baigaliyeva, Dauren Zhumabayev, Daniyar Malgazhdar, Damira Abudanash and Nurlan Ongdas in data collection at an early stage of the work.

\section{Author contributions}

Vadim Yapiyev conceived and planned the work, collected the observational data, conducted precipitation and evaporation analysis, wrote and edited the paper. Kanat Samarkhanov, Nazym Tulegenova, Saltanat Jumassultanova collected remote sensing data and conducted its analysis in GIS. Nursultan Umirov conducted water abstraction analysis. Kanat Samarkhanov, Zhanay Sagintayev, Nazym Tulegenova and Saltanat Jumassultanova prepared the map. Vadim Yapiyev and Zarina Saidaliyeva conducted climate analysis. Assel Namazbayeva provided evaporation pan data. Kanat Samarkhanov, Nazym Tulegenova, Saltanat Jumassultanova, Zarina Saidaliyeva, Nursultan Umirov, Zhanay Sagintayev, Assel Namazbayeva, and Anne Verhoef helped with data-interpretation, contributed to the text and edited the paper. The authors' names are provided in the order of contribution.

\section{Role of the funding source}

The founding sponsors had no role in the design of the study; in the collection, analyses, or interpretation of data; in the writing of the manuscript, and in the decision to publish the results.

\section{Declarations of interest}

None.

\section{Appendix A. Supplementary data}

Supplementary data to this article can be found online at https:// doi.org/10.1016/j.jaridenv.2018.09.008.

\section{References}

Bai, J., Chen, X., Li, J., Yang, L., Fang, H., 2011. Changes in the area of inland lakes in arid regions of central Asia during the past 30 years. Environ. Monit. Assess. 178, 247-256. https://doi.org/10.1007/s10661-010-1686-y.

Bai, J., Chen, X., Yang, L., Fang, H., 2012. Monitoring variations of inland lakes in the arid region of Central Asia. Front. Earth Sci. 6, 147-156. https://doi.org/10.1007/ s11707-012-0316-0.

Bennett, K.E., Gibson, J.J., McEachern, P.M., 2008. Water-yield estimates for critical loadings assessment: comparisons of gauging methods versus an isotopic approach. Can. J. Fish. Aquat. Sci. 65, 83-99. https://doi.org/10.1139/f07-155.

Blunden, J., Arndt, D.S., 2013. State of the climate in 2012. Bull. Am. Meteorol. Soc. 94, S1-S258. https://doi.org/10.1175/2013BAMSStateoftheClimate.1.

Blunden, J., Arndt, D.S., Baringer, M.O., 2011. State of the climate in 2010. Bull. Am. Meteorol. Soc. 92, S1-S236. https://doi.org/10.1175/1520-0477-92.6.S1.

Bronaugh, D., Werner, A., 2013. CRAN - package zyp [WWW document]. https://cran.rproject.org/web/packages/zyp/index.html, Accessed date: 8 December 2018.

Budyko, M.I., 1974. Climate and Life. Academic Press, New York.

Chen, Y., Li, Z., Fang, G., Li, W., 2018. Large hydrological processes changes in the transboundary rivers of Central Asia. J. Geophys. Res. Atmos 5059-5069. https://doi. org/10.1029/2017JD028184.

Dee, D.P., Uppala, S.M., Simmons, A.J., Berrisford, P., Poli, P., Kobayashi, S., Andrae, U., Balmaseda, M.A., Balsamo, G., Bauer, P., Bechtold, P., Beljaars, A.C.M., van de Berg, L., Bidlot, J., Bormann, N., Delsol, C., Dragani, R., Fuentes, M., Geer, A.J., Haimberger, L., Healy, S.B., Hersbach, H., H?lm, E.V., Isaksen, L., K?llberg, P., K?hler, M., Matricardi, M., McNally, A.P., Monge-Sanz, B.M., Morcrette, J.-J., Park, B.-K., Peubey, C., de Rosnay, P., Tavolato, C., Th?paut, J.-N., Vitart, F., Hólm, E.V., Isaksen, L., Kållberg, P., Köhler, M., Matricardi, M., McNally, A.P., Monge-Sanz, B.M., Morcrette, J.-J., Park, B.-K., Peubey, C., de Rosnay, P., Tavolato, C., Thépaut, J.-N., Vitart, F., 2011. The ERA-Interim reanalysis: configuration and performance of the data assimilation system. Q. J. R. Meteorol. Soc. 137, 553-597. https://doi.org/10. 1002/qj.828.

Donchyts, G., Baart, F., Winsemius, H., Gorelick, N., Kwadijk, J., van de Giesen, N., 2016. Earth's surface water change over the past 30 years. Nat. Clim. Change 6, 810-813. https://doi.org/10.1038/nclimate3111.

European Space Agency, 2018. KazEOSat-2 - satellite missions - eoPortal directory [WWW document] (accessed 5.28.18). https://directory.eoportal.org/web/eoportal/ satellite-missions/k/kazeosat-2.

Farr, T.G., Rosen, P.A., Caro, E., Crippen, R., Duren, R., Hensley, S., Kobrick, M., Paller, M., Rodriguez, E., Roth, L., 2007. The shuttle radar topography mission. Rev. Geophys. 45.

Finch, J., Calver, A., 2008. Methods for the Quantification of Evaporation from Lakes. Report 47.

Guo, H., Bao, A., Ndayisaba, F., Liu, T., Jiapaer, G., El-Tantawi, A.M., De Maeyer, P., 2018. Space-time characterization of drought events and their impacts on vegetation in Central Asia. J. Hydrol. 564, 1165-1178. https://doi.org/10.1016/J.JHYDROL. 2018.07.081.

Harbeck, G.E.J., 1962. A practical field technique for measuring reservoir evaporation utilizing mass-transfer theory. U. S. Geol. Surv. Prof. Pap. 272-E, 101-105.

Harris, I., Jones, P.D., Osborn, T.J., Lister, D.H., 2014. Updated high-resolution grids of monthly climatic observations - the CRU TS3.10 dataset. Int. J. Climatol. 34, 623-642. https://doi.org/10.1002/joc.3711.

Helsel, D., Hirsch, R., 2002. Statistical methods in water resources. Tech. WaterResources Investig. Book 4, 522. https://doi.org/10.2307/1269385.

Ireson, a. M., Barr, a. G., Johnstone, J.F., Mamet, S.D., van der Kamp, G., Whitfield, C.J., Michel, N.L., North, R.L., Westbrook, C.J., DeBeer, C., Chun, K.P., Nazemi, A., Sagin, J., September/October 2015. The changing water cycle: the Boreal Plains ecozone of Western Canada. Wiley Interdiscip. Rev. Water 2 (5), 505-552. https://doi.org/10. 1002/wat2.1098.

Jasechko, S., 2018. Plants turn on the tap. Nat. Clim. Change 8, 562-563. https://doi.org/ 10.1038/s41558-018-0212-z.

Kazhydromet, 2017. National hydrometeorological service of Kazakhstan [WWW document]. https://kazhydromet.kz/en/p/o-nacionalnoj-gidrometeorologiceskoj-sluzbekazahstana, Accessed date: 11 July 2017.

KazHydromet, 2014. Conducting Research to Comprehensively Address the Issue of Increasing Volume (Level) and Water Quality of Lakes in Schuchinsk - Borovoe Resort Territory. KazHydromet, Astana (In Russian).

Kendall, M.G., 1975. Rank Correlation Methods. Charles Griffin Book Series. Charles Griffin, London.

Klein, I., Dietz, A.J., Gessner, U., Galayeva, A., Myrzakhmetov, A., Kuenzer, C., 2014. Evaluation of seasonal water body extents in Central Asia over the past 27 years derived from medium-resolution remote sensing data. Int. J. Appl. Earth Obs. Geoinf. 26, 335-349. https://doi.org/10.1016/j.jag.2013.08.004.

Kopabayeva, A., Mazarzhanova, K., Köse, N., Akkemik, Ü., 2017. Tree-ring chronologies of Pinus sylvestris from Burabai Region (Kazakhstan) and their response to climate change. Dendrobiology 78, 96-110. https://doi.org/10.12657/denbio.078.010.

Mannig, B., Müller, M., Starke, E., Merkenschlager, C., Mao, W., Zhi, X., Podzun, R., Jacob, D., Paeth, H., 2013. Dynamical downscaling of climate change in Central Asia. Global Planet. Change 110, 26-39. https://doi.org/10.1016/j.gloplacha.2013.05. 008.

Mason, I.M., Guzkowska, M.A.J., Rapley, C.G., Street-Perrott, F.A., 1994. The response of lake levels and areas to climatic change. Climatic Change 27, 161-197. https://doi. org/10.1007/BF01093590.

McCabe, M.F., Rodell, M., Alsdorf, D.E., Miralles, D.G., Uijlenhoet, R., Wagner, W., Lucieer, A., Houborg, R., Verhoest, N.E.C., Franz, T.E., Shi, J., Gao, H., Wood, E.F., 2017. The future of Earth observation in hydrology. Hydrol. Earth Syst. Sci. 21, 3879-3914. https://doi.org/10.5194/hess-21-3879-2017.

McJannet, D., Hawdon, A., Van Niel, T., Boadle, D., Baker, B., Trefry, M., Rea, I., 2017. Measurements of evaporation from a mine void lake and testing of modelling approaches. J. Hydrol 631-647. D., Hawdon, A., Van Niel, T., Boadle, D., Bak. B., Trefry, M., Rea, I., 2017. Meas. evaporation from a mine void lake Test. Model. approaches. J. Hydrol. 555, 631-647. https//doi.org/10.1016/J.JHYDROL 555. https://doi.org/10.1016/J.JHYDROL.2017.10.064.

McJannet, D.L., Webster, I.T., Cook, F.J., 2012. An area-dependent wind function for estimating open water evaporation using land-based meteorological data. Environ. Model. Software 31, 76-83. https://doi.org/10.1016/j.envsoft.2011.11.017.

McMahon, T.A., Peel, M.C., Lowe, L., Srikanthan, R., McVicar, T.R., 2013. Estimating actual, potential, reference crop and pan evaporation using standard meteorological data: a pragmatic synthesis. Hydrol. Earth Syst. Sci. 17, 1331-1363. https://doi.org/ 10.5194/hess-17-1331-2013.

Milly, P.C.D., Dunne, K.A., 2016. Potential evapotranspiration and continental drying. Nat. Clim. Change 6, 6. https://doi.org/10.1038/NCLIMATE3046.

NASA, n.d. Landsat Science [WWW Document]. URL https://landsat.gsfc.nasa.gov/(accessed 10.9.2017).

Pekel, J.-F., Cottam, A., Gorelick, N., Belward, A.S., 2016. High-resolution mapping of global surface water and its long-term changes. Nature 1-19. https://doi.org/10. 1038/nature20584.

Propastin, P., 2012. Patterns of lake balkhash water level changes and their climatic correlates during 1992-2010 period. Lakes Reservoirs Res. Manag. 17, 161-169. https://doi.org/10.1111/j.1440-1770.2012.00508.x.

Roderick, M.L., Sun, F., Lim, W.H., Farquhar, G.D., 2014. A general framework for understanding the response of the water cycle to global warming over land and ocean. Hydrol. Earth Syst. Sci. 18, 1575-1589. https://doi.org/10.5194/hess-18-1575-2014.

Seddon, A.W., Macias-Fauria, M., Long, P.R., Benz, D., Willis, K.J., 2016. Sensitivity of global terrestrial ecosystems to climate variability. Nature 531, 229-232. https://doi. org/10.1038/nature16986.

Sen, P.K., 1968. Estimates of the regression coefficient based on Kendall's tau. J. Am. Stat. Assoc. 63, 1379-1389. https://doi.org/10.1080/01621459.1968.10480934.

Shaw, D.A., Vanderkamp, G., Conly, F.M., Pietroniro, A., Martz, L., 2012. The fill-spill hydrology of prairie wetland complexes during drought and deluge. Hydrol. Process. 
26, 3147-3156. https://doi.org/10.1002/hyp.8390.

Shikano, S., Kawano, K., Kudoh, J.I., Yurlov, A.K., Kikuchi, E., 2006. Intraannual and interannual changes in the surface area of a closed lake complex in southwestern Siberia using NOAA images. Limnology 7, 123-128. https://doi.org/10.1007/ s10201-006-0175-Z.

Vincke, C., Thiry, Y., 2008. Water table is a relevant source for water uptake by a Scots pine (Pinus sylvestris L.) stand: evidences from continuous evapotranspiration and water table monitoring. Agric. For. Meteorol. 148, 1419-1432. https://doi.org/10. 1016/j.agrformet.2008.04.009.

Woolway, R.I., Merchant, C.J., 2017. Amplified surface temperature response of cold, deep lakes to inter-annual air temperature variability. Sci. Rep. 7, 4130. https://doi. org/10.1038/s41598-017-04058-0.

Xiao, K., Griffis, T.J., Baker, J.M., Bolstad, P.V., Erickson, M.D., Lee, X., Wood, J.D., Hu, C., Nieber, J.L., 2018. Evaporation from a temperate closed-basin lake and its impact on present, past, and future water level. J. Hydrol. 561, 59-75. https://doi.org/10. 1016/j.jhydrol.2018.03.059.

Xu, H., 2006. Modification of normalised difference water index (NDWI) to enhance open water features in remotely sensed imagery. Int. J. Rem. Sens. 27, 3025-3033. https:// doi.org/10.1080/01431160600589179.

Yapiyev, V., Sagintayev, Z., Inglezakis, V.J.V., Samarkhanov, K., Verhoef, A., 2017a. Essentials of endorheic basins and lakes: a review in the context of current and future water resource management and mitigation activities in central Asia. Water 2017, Vol. 9, Page 798 9, 798. https://doi.org/10.3390/W9100798.

Yapiyev, V., Sagintayev, Z., Verhoef, A., Kassymbekova, A., Baigaliyeva, M.,

Zhumabayev, D., Malgazhdar, D., Abudanash, D., Ongdas, N., Jumassultanova, S., September/October 2017b. The changing water cycle: Burabay National Nature Park, northern Kazakhstan. Wiley Interdiscip. Rev. Water 4 (5), e1227. https://doi.org/10. 1002/wat2.1227.

Yapiyev, V., Verhoef, A., Sagintayev, Z., 2018. The multi-year (2008-2016) water and energy balance of three small endorheic lakes in Burabay National Nature Park, Kazakhstan, Northern Central Asia. In: EGU General Assembly 2018. Vienna, pp. 15223.

Zhang, B., Wu, Y., Zhu, L., Wang, J., Li, J., Chen, D., 2011. Estimation and trend detection of water storage at Nam Co Lake, central Tibetan Plateau. J. Hydrol. 405, 161-170. https://doi.org/10.1016/j.jhydrol.2011.05.018. 